\title{
ZNAČAJAN UTJECAJ OBLIKA PROIZVODA NA VRIJEDNOST PROIZVODA KAO APSOLUTNA PREPREKA ZA REGISTRACIJU ŽIGA**
}

Sažetak: Rad pruža sveobuhvatnu analizu pravila prema kojem kao žig nije moguće registrirati oblik ili drugo obilježje proizvoda koje značajno determinira vrijednost proizvoda. Riječ je o pravilu koje je u sustavu žigovnog prava EU-a kodificirano kao članak 4 (1) (e) (iii) Direktive (EU) 2015/2436 o uskladivanju zakonodavstava država članica o žigovima, odnosno kao članak 7 (1) (e) (iii) Uredbe (EU) 2017/1001 o žigu EU-a.

Cilj rada je trojak: a) definirati ratio legis odredbe prema kojoj kao žig nije moguće registrirati oblik ili drugo obilježje proizvoda koje značajno utječe na vrijednost proizvoda; $b$ ) ponuditi temeljitu analizu relevantne sudske prakse s područja EU-a te c) na temelju provedene analize ocijeniti treba li ovo pravilo pro futuro opstati u neizmijenjenu obliku ili bi svrsishodnije bilo ukinuti ga, odnosno izmijeniti. Imajući u vidu svrhu analiziranog pravila (s jedne strane) te probleme do kojih dolazi pri njegovoj primjeni u praksi (s druge strane), u zaključku rada nude se smjernice u skladu s kojima bi navedeno pravilo trebalo tumačiti i primjenjivati u praksi.

Ključne riječi: značajna vrijednost oblika proizvoda, doktrina estetske funkcionalnosti, apsolutne prepreke za registraciju žiga, oblikovni žigovi, 3D žigovi 52100 Pula. E-adresa: thasic@unipu.hr. ORCID: https://orcid.org/0000-0001-6079-1156.

** Rad je izrađen u okviru znanstvenog projekta Organizacijski i pravni izazovi u suvremenom poduzetničkom okruženju pri Fakultetu ekonomije i turizma "Dr. Mijo Mirković", Sveučilište Jurja Dobrile u Puli. Mišljenja, nalazi i zaključci ili preporuke navedene u ovom radu odnose se na autora i ne odražavaju nužno stajališta Fakulteta ekonomije i turizma "Dr. Mijo Mirković" Pula. 


\section{UVOD}

Tradicionalno se ratio legis zaštite autorskih prava, patenata i prava industrijskog dizajna, uvelike razlikuje od ratia zaštite žigova kao subjektivnih prava nad razlikovnim znakovima. Naime, autorska prava, patent i industrijski dizajn, njihovim nositeljima osiguravaju svojevrstan monopol (tj. isključiva prava) nad proizvodom (tj. nad izumom, autorskim djelom ili vanjskim izgledom proizvoda) iz čega proizlazi da treće osobe, bez njihova odobrenja, ne mogu kopirati, imitirati ili na bilo koji drugi način koristiti djela pod zaštitom. Ipak, navedeno ograničenje nije apsolutno - budući da su isključiva prava autora, nositelja patenta ili nositelja industrijskog dizajna, teritorijalno, ${ }^{1}$ vremenski, ${ }^{2}$ a u određenoj mjeri i sadržajno ograničena. ${ }^{3}$ Navedena isključiva prava intelektualnog vlasništva imaju za cilj potaknuti kreativne pojedince na stvaranje izuma, na kreiranje originalnih autorskih djela, odnosno na stvaranje uporabnih predmeta novog ili originalnog vanjskog izgleda. Pobuda za stvaranjem očituje se u tome što zahvaljujući subjektivnim pravima intelektualnog vlasništva (na određenom području i u određenom periodu) kreativni pojedinci imaju monopol nad komercijalnom eksploatacijom zaštićenih dobara - pri čemu ih eksploatirati mogu samostalno ili uz posredovanje trećih osoba. ${ }^{4}$ Po isteku razdoblja u kojemu su isključiva prava pripadala njihovim nositeljima, objekt koji je bio pod zaštitom ulazi u tzv. javnu domenu te se njime svatko može slobodno koristiti. ${ }^{5}$ Dakle, ultimativni ratio autorskog prava, patentnog prava (ali i prava industrijskog dizajna) jest osigurati i potaknuti napredak društva kao cjeline. ${ }^{6}$

1 Patent i pravo industrijskog dizajna stječu se registracijom te imaju učinak na području nadležnosti registarskog tijela - što se, uglavnom, poklapa s nacionalnim granicama. Prema većini nacionalnih pravnih rješenja, za stjecanje autorskih prava nije potrebna registracija. Trenutak nastanka, sadržaj subjektivnih prava, način prijenosa, ali i prestanak autorskih prava, uređeni su na nacionalnim razinama te se mogu razlikovati od države do države. Moguće je da (prema pravnom poretku jedne države) autorsko pravo nad određenim djelom postoji, dok (prema pravnom poretku druge države) ne postoji. Primjerice, ako je riječ o djelu koje je stvoreno, ali nije fiksirano - budući da neke države fiksaciju djela na trajni medij predviđaju kao preduvjet za nastanak autorskog prava, a neke ne.

2 U većini zemalja patentno pravo vremenski je ograničeno na period od dvadeset godina, računajući od datuma podnošenja prijave za registraciju patenta. Autorska prava, u većini zemalja, traju sedamdeset godina post mortem auctoris (iako, tzv. moralna prava autora, u mnogim zemljama, nisu vremenski ograničena). Prava industrijskog dizajna također su vremenski ograničena subjektivna prava, ali (na globalnoj razini) nacionalna prava nisu ujednačena kada je o trajanju prava industrijskog dizajna riječ. Na području Europske unije, registrirana prava industrijskog dizajna ne mogu trajati dulje od dvadeset i pet godina, $s$ time da se moraju obnavljati svakih pet godina, dok tzv. neregistrirana prava industrijskog dizajna (kakva, prema našim saznanjima, ne postoje drugdje u svijetu), traju tri godine i ne mogu se obnavljati.

3 Različita nacionalna rješenja predviđaju različita sadržajna ograničenja za sva prava intelektualnog vlasništva. Uglavnom je riječ o ograničenjima kojima se dopušta uporaba navedenih prava (bez plaćanja naknade i/ili bez ičijeg odobrenja) za privatne ili nekomercijalne svrhe, za obrazovne svrhe i sl.

4 Primjerice, na temelju ugovora mogu ovlastiti treće osobe za korištenje njihova patenta, autorskog prava ili prava industrijskog dizajna - pri čemu mogu ugovoriti različite oblike naknada.

5 Uz poštovanje tzv. moralnih prava, koja (ako su predviđena nacionalnim pravnim rješenjima) mogu trajati i u neograničenom periodu.

6 Ovaj cilj jasno je izražen još u prvoj verziji teksta Ustava SAD-a (iz 1787. godine) gdje se u tzv. "intellectual property clause” (poznatijom i pod nazivom "progress clause") navodi: "United States Congress shall have power (...) to promote the progress of science and useful arts, by securing for limited times to authors and inventors the exclusive right to their respective writings and discoveries" - vidjeti: art. 1. sec. 8. clause 8. američkog Ustava, koji je dostupan na sljedećoj poveznici: http:// constitutionus.com/. Pristupljeno 1. veljače 2020. Slično ističe i Državni zavod za intelektualno vlasništvo (dalje: DZIV): "Kako bi se zaštitila ova vrsta dobara, te na taj način potakla ljudska kreativnost koja doprinosi općem društvenom razvitku, razvijen je odgovarajući sustav pravne zaštite intelektualnog vlasništva", dostupno na: https://www.dziv.hr/hr/intelektualno-vlasnistvo/ o-intelektualnom-vlasnistvu/. Pristupljeno 1. veljače 2020. O svrsi prava intelektualnog vlasništva, vidjeti više u: Karjala, D., Sustainability and Intellectual Property Rights in Traditional Knowledge, Jurimetrics, br. 53, 2012., str. 59.-62. 
S druge strane, svrha je žigovnog prava na tržištu omogućiti razlikovanje proizvoda (ili usluga $)^{7}$ jedne osobe od istovjetnih ili sličnih proizvoda njezinih konkurenata. ${ }^{8}$ Žig je, dakle, isključivo pravo koje njegov nositelj ima nad znakom kojim označava svoje proizvode, kako bi ih potrošači mogli razlikovati od proizvoda njegovih konkurenata. Kada bi tržišni takmaci slobodno mogli koristiti razlikovne znakove svojih konkurenata, potrošači bi bili dovedeni u zabludu, a nelojalni "igrači” mogli bi se okoristiti ugledom svojih konkurenata te ga, posljedično, i (nepovratno) narušiti. Zdrava tržišna konkurencija u interesu je javnosti - stoga je zadaća zakonodavca osigurati mjere koje mogu (bez vremenskog ograničenja) osigurati fer tržišnu utakmicu. Jedna od takvih mjera je i uspostavljanje sustava zaštite razlikovnih znakova (žigova), nad kojima isključiva prava mogu trajati sve dok njihov nositelj ima potrebu za njihovom zaštitom te dok ispunjava za to propisane uvjete - što (potencijalno) može trajati unedogled. ${ }^{9}$ Upravo radi različite svrhe koja se u okviru žigovnog prava želi ostvariti, pravo žiga (potencijalno) može trajati neograničeno dugo, dok autorska prava, patenti te prava industrijskog dizajna imaju ograničeno vremensko trajanje. ${ }^{10}$

Ipak, ovu "shemu" u određenoj mjeri narušavaju nekonvencionalni žigovi, ${ }^{11}$ kojima se štite specifični razlikovni znakovi - kao što su oblik proizvoda, boja proizvoda, tekstura proizvoda, okus ili miris proizvoda i sl., a koji u suštini predstavljaju određen segment (dio) proizvoda. Ovakvim se žigovima (potencijalno) omogućava stjecanje permanentnog monopola nad određenim segmentima proizvoda (npr. nad određenom bojom proizvoda, nad oblikom ili teksturom proizvoda i sl.) što znači da se konkurenti navedenim segmentima proizvoda neće moći koristiti, i to u neograničenom periodu.

Stoga se postavlja pitanje: je li ovakva regulativa protivna pravilima o zaštiti konkurencije koja imaju za cilj osigurati slobodnu konkurenciju na tržištu? Nadalje, postavlja se i pitanje: zaobilaze li se, ovakvom regulativom, kogentne zakonske norme o vremenski ograničenom trajanju drugih prava intelektualnog vlasništva koja štite proizvode, odnosno njihove segmente (na primjer, vanjski izgled proizvoda) kao intelektualne tvorevine (patent, autorsko pravo, pravo industrijskog dizajna)?

Kako bi ublažio učinak koji nekonvencionalni žigovi mogu imati na tržišnu utakmicu, ali i kako bi smanjio broj situacija u kojima se nekonvencionalnim žigovima de facto produljuju vremenski ograničena prava intelektualnog vlasništva, europski zakonodavac predvidio je dodatne apsolutne prepreke koje se (uz redovite apsolutne prepreke - koje se primjenjuju na bilo koju vrstu znakova koje se želi registrirati kao žig) primjenjuju samo kada se kao žig želi registrirati znak koji predstavlja oblik proizvoda. Ove dodatne apsolutne prepreke, od posljed-

7 Iako se pravo žiga može odnositi i na proizvode i na usluge, u daljnjem tijeku rada nećemo posebno isticati da se žigovima mogu označavati i usluge.

8 Slično i DZIV: “Žig (...) služi za razlikovanje proizvoda i/ili usluga jedne osobe od ostalih osoba u gospodarskom prometu”, dostupno na: https://www.dziv.hr/hr/intelektualno-vlasnistvo/zigovi/. Pristupljeno 1. veljače 2020.

9 Prema većini nacionalnih rješenja pravo žiga može trajati u neograničenom periodu, ali se mora periodično obnavljati. Uglavnom je predviđeno da se žigovi moraju obnavljati svakih deset godina. Vidjeti: DZIV, https://www.dziv.hr/hr/intelektualnovlasnistvo/zigovi/. Pristupljeno 1. veljače 2020.

10 Tako i: Rosati, E.; The absolute ground for refusal or invalidity in Article 7 (1) (e) (iii) EUTMR / 4 (1) (e) (iii) EUTMD: in search of the ecxlusion's own substantial value, Journal of Intellectual Property Law \& Practice, god. 15, br. 2, 2020., str. 6.

11 Tako: Kur, A.; Too common, too splendid or just right? Trademark protection for product shapes in light of CJEU case law, Max Planck Institute for Innovation and Competition Research Paper Series, Research Paper, br. 14-17, 2014., str. 2. 
nje se revizije žigovnog prava EU-a, ${ }^{12}$ nedvojbeno primjenjuju i u situacijama kada se ostala obilježja proizvoda (npr. boja per se, tekstura proizvoda, miris ili okus proizvoda i sl.) žele registrirati kao žig. ${ }^{13} \mathrm{U}$ nastavku rada detaljnije ćemo pojasniti navedene dodatne apsolutne prepreke, a zasad je dovoljno naznačiti da je riječ o pravilima zahvaljujući kojima kao žig nije moguće registrirati oblik proizvoda koji je prirodan, funkcionalan ili privlačan. ${ }^{14}$ Nužno je istaknuti i to da su sve apsolutne prepreke za registraciju žiga koje ćemo (u manjoj ili većoj mjeri) analizirati u radu, ujedno i razlozi na temelju kojih se ništetnima mogu utvrditi već registrirani žigovi - što u nastavku rada nećemo posebno isticati.

Iako ćemo u radu (u drugom poglavlju) ukratko prikazati sve dodatne prepreke za registraciju oblika proizvoda kao žiga, cilj rada je pružiti sveobuhvatnu analizu pravila prema kojem kao žig nije moguće registrirati oblik proizvoda koji značajno determinira vrijednost proizvoda. Riječ je o pravilu kojim je, na području EU-a (u određenoj mjeri ${ }^{15}$ ) prihvaćena tzv. doktrina estetske funkcionalnosti razvijana dugi niz godina u sudskoj praksi na području SAD-a. Prema doktrini estetske funkcionalnosti ne mogu se kao žig registrirati vanjska obilježja proizvoda koja su estetski privlačna, kako bi se takvim obilježjima (koje potrošači na proizvodima iste vrste priželjkuju) mogli koristiti i konkurenti. ${ }^{16}$ Beneluški Zakon o žigu iz 1975 . godine, ${ }^{17}$ prvi je pravni akt kojim je na području današnjeg EU-a (u određenoj mjeri) prihvaćena američka dok-

12 Pod sintagmom "posljednja revizija žigovnog prava na području EU-a" mislimo na usvajanje Direktive (EU) 2015/2436 Europskog parlamenta i Vijeća od 16. prosinca 2015. godine o usklađivanju zakonodavstava država članica o žigovima, Službeni list EU-a, L 336/1 (23. prosinca 2015.), str. 1.-26. (dalje u tekstu: Direktiva 2015/2436) te na usvajanje Uredbe (EU) 2015/2424 Europskog parlamenta i Vijeća od 16. prosinca 2015. godine o izmjeni Uredbe Vijeća (EZ) br. 207/2009 o žigu Zajednice i Uredbe Komisije (EZ) br. 2868/95, o provedbi Uredbe Vijeća (EZ) br. 40/94 o žigu Zajednice te o stavljanju izvan snage Uredbe Komisije (EZ) br. 2869/95 o pristojbama koje se plaćaju Uredu za usklađivanje na unutarnjem tržištu (žigovi i dizajni), koja je kodificirana kao Uredba (EU) 2017/1001 Europskog parlamenta i Vijeća od 14. lipnja 2017. godine o žigu Europske unije, Službeni list EU-a, L 154/1 (16. lipnja 2017), str. 1.-99. (dalje u tekstu: Uredba 2017/1001).

13 Prije posljednje revizije žigovnog prava (iz 2015. godine) među pravnim teoretičarima postojala je dvojba primjenjuju li se dodatne apsolutne prepreke za registarciju oblika proizvoda kao žiga i na ostala obilježja proizvoda ili ne, a ni sudska praksa u vezi s tim pitanjem nije bila konzistentna - o čemu će više govora biti infra, u dijelu 3.2.2.

14 Slično i: AG Ruiz-Jarabo Colomer, u mišljenju u povodu predmeta Koninklijke Philips Electronics NV v Remington Consumer Products Ltd., C-299/99 (dalje u tekstu: Philips ili Philips v. Remington) gdje takve (neregistrabilne) oblike naziva "prirodnim, funkcionalnim i ornamentalnim oblicima" - citirano prema: Cornish, W. R.; Llewelyn, D.; Aplin, T., Intellectual Property: Patents, Copyright, Trade Marks and Allied Rights- eight edition, Sweet and Maxwell, London, UK, 2013., str. 729.

15 Pravilo implementirano u pravni sustav EU-a, prema kojem značajan utjecaj oblika na vrijednost proizvoda predstavlja apsolutnu prepreku za registraciju žiga, nema istovjetno polje primjene kao i pravilo koje proizlazi iz američke doktrine "aesthetic functionality" - koje se (nedvojbeno) primjenjuje na bilo koje vanjsko obilježje proizvoda, a ne samo na oblik (što na području EU-a nedvojbeno vrijedi tek od posljednje revizije žigovnog prava iz 2015. godine), ali se odnosi samo na obilježja koja imaju estetsku funkciju, no ne i na obilježja koja zbog nekog drugog razloga (osim estetskog) utječu na vrijednost proizvoda. Ipak, američki sudovi skloni su široko tumačiti sintagmu "estetska funkcija" stoga Hughes smatra da bi naziv doktrine trebao biti doktrina kognitivne percepcije, umjesto doktrina estetske funkcije. Vidjeti: Hughes, J., Cognitive and aesthetic functionality in trademark law, Loyola - LA Legal studies paper, br. 2015-07, 2015., str. 120.-128.

16 Više o doktrini estetske funkcionalnosti (kojom se u ovom radu, na način kako ju se definira i primjenjuje na području SAD-a, nećemo baviti) vidjeti u: Ibidem, str. 101.-156. I na području SAD-a javljaju se brojni problemi kada ovu doktrinu treba primijeniti u praksi - primjerice, kako definirati što je, kome je, na kojem području i u kojem trenutku estetski privlačno? Obuhvaća li estetska privlačnost samo "oku ugodna obilježja" ili i obilježja koja su potrošačima privlačna zbog nekog drugog razloga - npr. jer su udobna?

17 Benelux Merkenwet (BMW) ili u prijevodu na engleski jezik Uniform Trade Mark Act of the Benelux countries. Više o navedenom Zakonu, vidjeti u: Gielen, C., Substantial Value Rule: How it Came into Being and Why it Should be Abolished, European Intellectual Property Review, br. 3, 2014., str. 165.-166.; Kur, A., Too Pretty to Protect? Trade Mark Law and Enigma of Aesthetic Funcionality, Max Planck Institute for Intellectual Property and Competition Law Research Paper, br. 11-16, 2011., str. 7.-10.; Rosati, op. cit. u bilj. 10, str. 4 . 
trina estetske funkcionalnosti. ${ }^{18}$ Vjeruje se da je upravo pravilo sadržano u beneluškom Zakonu o žigu iz 1975. godine - prema kojem kao žig nije bilo moguće registrirati oblike proizvoda koji proizlaze iz prirode proizvoda, koji su isključivo uvjetovani tehničkom funkcijom proizvoda ili koji značajno utječu na vrijednost proizvoda ${ }^{19}$ - poslužilo kao uzor europskom zakonodavcu pri usvajanju Direktive o usklađivanju zakonodavstava država članica o žigovima iz 1989. godine. ${ }^{20}$ Riječ je o pravilu koje je danas sadržano u članku 4. (1) (e) (iii) Direktive 2015/2436 ${ }^{21}$ te je, posljedično, implementirano u nacionalne pravne poretke zemalja članica EU-a. ${ }^{22} \mathrm{U}$ istovjetnom obliku sadržano je i u članku 7. (1) (e) (iii) Uredbe 2017/1001 o žigu EU-a. ${ }^{23}$ Ovo pravilo veoma je nejasno i neprecizno te, kao takvo, predstavlja izvor pravne nesigurnosti i nepredvidljivosti. ${ }^{24}$ Stoga, određeni pravni teoretičari smatraju da bi navedeno pravilo trebalo ukinuti jer se (prema njihovu stajalištu) njegova funkcija može ostvariti primjenom drugih pravila. ${ }^{25}$ Drugi su nešto umjereniji te smatraju da bi navedeno pravilo trebalo opstati (što podupiru tvrdnjom da se funkcija navedenog pravila ne može ostvariti primjenom drugih pravila), ali svejedno naglašavaju kako sporno pravilo ne bi smjelo opstati u sadašnjem "obliku”, već bi ga trebalo doraditi i precizirati kako bi prestalo biti izvorom pravne nesigurnosti i nepredvidljivosti. ${ }^{26}$

Praksa Suda Europske unije (i Europskog suda i Općeg suda) poprilično je oskudna kada je o primjeni navedenog pravila riječ, baš kao što je oskudna i sudska praksa nacionalnih sudova zemalja članica EU-a, ali i praksa EUIPO-a (odnosno, prije OHIM-a). ${ }^{27}$ Ipak, u nastavku rada (gdje analiziramo relevantne odluke iz prakse) vidjet ćemo kako je sudska praksa (iako oskudna) prilično nekonzistentna kada je o primjeni pravila o značajnoj vrijednosti oblika proizvoda kao prepreci za registraciju žiga riječ - što svakako podupire tezu da ovo pravilo uzrokuje pravnu nesigurnost i nepredvidljivost.

18 Prema: Kur, op. cit. u bilj. 17, str. 8., nije iznenađujuće što je beneluški zakonodavac prvi na području današnjeg EU-a u pozitivnopravnu legislativu odlučio implementirati rješenja uspostavljena u američkoj sudskoj praksi, budući da su nizozemski zakonodavci i prije bili otvoreni prema inozemnim (posebice, američkim) rješenjima, što nije karakteristično za europske zemlje tzv. germanskog ili romanskog pravnog kruga.

19 Prema članku 1. (2) beneluškog Zakona o žigu iz 1975. godine.

Direktiva 89/104 EEZ od 21. prosinca 1988. godine o usklađivanju zakonodavstava država članica o žigovima, Službeni list EU-a, L 40 (11. veljače 1989.), str. 1.-7. (dalje u tekstu: Prva direktiva o usklađivanju žigovnog prava ili Direktiva 89/104/EEZ). Ovu Direktivu zamijenila je Direktiva 2008/95/EZ od 22. listopada 2008. godine o usklađivanju zakonodavstava država članica o žigovima - kodificirana verzija, Službeni list EU-a, L 299/25 (8. studenoga 2008.), str. 149.-157. (dalje u tekstu: Druga direktiva o harmonizaciji žigovnog prava ili Direktiva 2008/95/EZ).

21 U tzv. Prvoj i Drugoj direktivi o harmonizaciji žigovnog prava, ovo pravilo bilo je sadržano u članku 3. (1) (e) (iii). Prema hrvatskom Zakonu o žigu, Narodne novine, broj 14/2019, ovo pravilo sadržano je u članku 9. (1) (5) (c), a glasi: "Neće se registrirati (...) znakovi koji se sastoje isključivo od: (...) oblika, ili drugog obilježja, koji proizvodima daje bitnu vrijednost." I u prijašnjoj Uredbi (o žigu EZ-a) ovo pravilo bilo je sadržano u članku 7. (1) (e) (iii). Tako i: Kur, op. cit. u bilj. 17, str. 1. i 21., Gielen, op. cit. u bilj. 17, str. 168.

25 Npr. Gielen, op. cit. u bilj. 17, str. 169.; Max Planck Institute for Intellectual Property and Competition Law, Study on the Overall Functioning of the European Trade Mark System, Munich, 2011. https://www.ip.mpg.de/fileadmin/IP/pdf2/mpi-final-report-withsynopsis.pdf. Pristupljeno 28. travnja 2020., str. 74. .: "Article 7 (1) (e) (iii) CTMR and Article 3 (1) (e) (iii) TMD should be deleted or replaced by a provision stating that shapes determining the commercial value of the goods are excluded from protection, unless the commercial value of the shape has become distinctive through use." zadržati (uz određene izmjene i drugačije tumačenje), iako kritizira način na koji je ovo pravilo implementirano u pozitivnopravnu EU-ovu legislativu te način na koji ga ES tumači. 
Cilj rada je:

1.) definirati ratio legis odredbe prema kojoj kao žig nije moguće registrirati oblik proizvoda koji značajno utječe na vrijednost proizvoda

2.) analizirati dostupnu sudsku praksu (s područja EU-a) gdje je ovo pravilo primijenjeno ili protumačeno

3. na temelju provedene analize ocijeniti treba li ovo pravilo opstati u neizmijenjenu obliku, ili bi svrsishodnije bilo ukinuti ga, odnosno doraditi i precizirati.

\section{APSOLUTNE PREPREKE KOJE SE PRIMJENJUJU KADA SE KAO ŽIG ŽELI REGISTRIRATI OBLIK PROIZVODA}

Iako su pojedini pravni teoretičari isticali da oblik proizvoda ne bi trebalo smatrati razlikovnim znakom te mu, posljedično, ne bi trebalo osigurati mogućnost zaštite u okviru žigovnog prava, ${ }^{28}$ većina suvremenih pravnih teoretičara ipak ne podupire ovako ekstremna stajališta. ${ }^{29}$ Oni smatraju da suvremene marketinške aktivnosti sve više pridaju značaj tzv. sensory brandingu, odnosno nekonvencionalnim marketinškim znakovima, kao što su: boja, zvuk, tekstura, oblik ili miris proizvoda te, stoga, i takvim znakovima (ako su na tržištu postali razlikovni) treba osigurati mogućnost zaštite u okviru žigovnog prava. ${ }^{30}$ Ovom se stavu (u određenoj mjeri $)^{31}$ priklonio i europski zakonodavac, koji je pri usvajanju Prve direktive o harmonizaciji žigovnog prava iz 1989 godine, izričito naveo da se kao žig može registrirati i nekonvencionalni znak koji sadržajno predstavlja oblik proizvoda. ${ }^{32}$ Ipak, europski je zakonodavac (očito uvažavajući činjenicu da je ovdje riječ o specifičnom znaku koji se sadržajno preklapa s objektom, tj. s proizvodom koji označava) izričito propisao i tri dodatne apsolutne prepreke, ${ }^{33}$ koje nije moguće naknadno prevladati, ${ }^{34}$ a koje se primjenjuju kada se kao žig želi registrirati znak koji

28 Ovi autori vođeni su tezom da se žigovnim pravom tržišna konkurencija ne bi smjela ograničavati, već podupirati - što, smatraju, kod žigova koji se isključivo sastoje od oblika proizvoda, nije slučaj. Vidjeti, npr. Kur, A., Senftleben, M., European Trademark Law - A Commentary, Oxford University Press, Oxford, UK, 2017., par. 4.143 i par. 4.152-4.154. Prije usklađivanja s Prvom direktivom o usklađivanju žigovnog prava zemalja članica iz 1989. godine, na području Velike Britanije nije bilo moguće kao žig registrirati znak koji se isključivo sastojao od oblika proizvoda - prema, Cornish; Llewelyn; Aplin, op. cit. u bilj. 14 , str. 727.

Kažemo "u određenoj mjeri" budući da su se žiga). Zbog ovog je razloga na području EU-a znatno manje registriranih nekonvencionalnih žigova, nego na području SAD-a (npr. mirisnih, okusnih, pa čak i zvučnih - jer se ne mogu svi zvukovi grafički prikazati notnim zapisom). Iako je zakonodavac EU-a 2015. godine uklonio uvjet grafičkog prikaza, na području EU-a i dalje je znatno teže registrirati nekonvencionalne žigove, nego na području SAD-a, budući da (prema novoj legislativi) znak koji se želi registrirati kao žig, mora biti prikazan na način koji je: jasan, precizan, samostalan, lako dostupan, razumljiv, postojan i objektivan (Direktiva 2015/2436 - preambula, par. 13.). Riječ je o uvjetima koje je uspostavio ES u predmetu Sieckmann (C-273/00 od 12. prosinca 2002. godine), a koje mnogi nekonvencionalni znakovi (npr. miris i okus) veoma teško mogu zadovoljiti u praksi. Više o nekonvencionalnim žigovima na području EU-a i SAD-a, vidjeti u: Krpan, P. Nekonvencionalni žigovi, Pravnik, god. 48, br. 1 (96), 2014., str. 63.-74.

Direktiva 89/104/EEZ, članak 2.

Direktiva 89/1047EEZ, članak 3. (1) (e).

Prema članku 3. (3) Direktive 89/104/EEZ neke apsolutne prepreke za registraciju žiga (tj. opisnost i generičnost) ne primjenjuju se ako je znak postao razlikovan. Stoga, takve prepreke nazivamo prevladivim apsolutnim preprekama. Kako se navedeni članak ne primjenjuje na dodatne apsolutne prepreke za registraciju oblika proizvoda kao žiga, slijedi da su te prepreke neprevladive. 
predstavlja oblik proizvoda. ${ }^{35}$ Riječ je o pravilima koja su danas sadržana u članku 4. (1) (e) Direktive (EU) 2015/2436 te u članku 7. (1) (e) Uredbe (EU) 2017/1001.

Zahvaljujući ovim odredbama, na području EU-a (bilo na regionalnoj, bilo na nacionalnoj razini) kao žig nije moguće registrirati znak koji se isključivo sastoji od:

a) oblika proizvoda koji proizlazi iz prirode samog proizvoda - članak 7. (1) (e) (i) Uredbe (EU) 2017/1001 i članak 4. (1) (e) (i) Direktive (EU) 2015/2436

b) oblika koji je nužan za ostvarivanje tehničkog rezultata proizvoda (tj. koji ima tehničku funkciju) - članak 7. (1) (e) (ii) Uredbe (EU) 2017/1001 i članak 4. (1) (e) (iii)

c) oblika koji proizvodu daje značajnu vrijednost - članak 7. (1) (e) (iii) Uredbe (EU) 2017/1001 i članak 4. (1) (e) (iii) Direktive (EU) 2015/2436.

Niti pri usvajanju navedenih odredbi, niti pri njihovu revidiranju (2015. godine) - kada je polje primjene navedenih odredbi izričito prošireno i na ostala obilježja proizvoda - europski zakonodavac nije obrazložio njihov ratio, odnosno svrhu koja se njima želi ostvariti. ${ }^{36}$ Stoga ćemo ratio navedenih odredbi (posebice ratio odredbe o nemogućnosti registracije žiga kada je riječ o obliku koji proizvodu daje značajnu vrijednost) nastojati odrediti u nastavku rada, analizirajući relevantne odluke iz prakse.

Oblik proizvoda, osim što mora udovoljiti navedenim dodatnim apsolutnim preprekama za registraciju žiga (koje su "nepremostive" - budući da se ne mogu naknadno prevladati ako oblik postane razlikovan) mora udovoljiti i svim ostalim (općim) apsolutnim preprekama za registraciju žiga - koje se primjenjuju neovisno o tome je li znak koji se želi registrirati kao žig konvencionalan ili ne. ${ }^{37}$ Među općim apsolutnim preprekama za registraciju žiga posebno se ističu pravila prema kojima se kao žig ne može registrirati znak koji je opisan, ${ }^{38}$ generičan $^{39}$ ili koji nije razlikovan (odnosno distinktivan). ${ }^{40}$ Iako kažemo da su ove prepreke za registraciju žiga apsolutne - jer su sadržane u samom znaku koji se želi registrirati kao žig, ${ }^{41}$ one su ipak "premostive" - budući da neće imati utjecaja ako znak koji se želi registrirati kao žig naknadno postane razlikovan na temelju uporabe. ${ }^{42}$

35 Od posljednje revizije žigovnog prava EU-a više nije sporno primjenjuju li se te odredbe i na ostale karakteristike proizvoda. U prošlosti je ovo bilo sporno jer odluke iz prakse nisu bile konzistentne. O ovome će više govora biti u nastavku rada (infra, u dijelu 3.2.2.). Stoga ćemo (do dijela 3.2.2.) govoriti o dodatnim preprekama za registraciju "oblika proizvoda" kao žiga, dok ćemo od dijela 3.2.2. nadalje govoriti o dodatnim apsolutnim preprekama za registraciju "oblika ili druge karakteristike proizvoda" kao žiga.

36 Kur, op. cit. u bilj. 17, na str. 9. ističe kako motiv europskog zakonodavca (za implementaciju beneluškog rješenja u europski sustav žigovnog prava) nije izričito navedeno niti u zv. pripremnim dokumentima.

37 Apsolutne prepreke za registraciju žiga propisane su člankom 4. (1) Direktive (EU) 2015/2436 i člankom 7. (1) Uredbe (EU)2017/1001.

38 Direktiva (EU) 2015/2436, članak 4. (1) (c) i Uredba (EU) 2017/1001, članak 7. (1) (c).

39 Direktiva (EU) 2015/2436, članak 4. (1) (d) i Uredba (EU) 2017/1001, članak 7. (1) (d).

40 Direktiva (EU) 2015/2436, članak 4. (1) (b) i Uredba (EU) 2017/1001, članak 7. (1) (b).

41 Više o apsolutnim preprekama za registraciju žiga, vidjeti u: Rački Marinković, A., Apsolutni i relativni razlozi za odbijanje registracije žiga: usporedba nekih aspekata europskog i hrvatskog prava te prakse OHIM-a i DZIV-a, objavljeno u: Matanovac Vučković, R. (ur.), Hrvatsko pravo intelektualnog vlasništva u svjetlu pristupanja Europskoj uniji, Narodne novine i Državni zavod za intelektualno vlasništvo, Zagreb, 2006. str. 1.-52. 
Iako je ES u više navrata istaknuo da se "opće” apsolutne prepreke (kao što je razlikovnost) trebaju procjenjivati na jednak način, neovisno o tome je li podnesena prijava za registraciju konvencionalnog ili nekonvencionalnog žiga, ${ }^{43}$ ipak je razvio tumačenje prema kojem, u odnosu na uobičajene marketinške znakove (kao što su, primjerice, grafički simboli ili verbalni znakovi) koje potrošači redovito doživljavaju kao razlikovne znakove, postoji značajno slabija vjerojatnost da će potrošači manje uobičajene znakove (kao što su: boja per se, reklamni slogani ili oblik proizvoda) doživjeti kao razlikovne znakove. ${ }^{44}$ Mnogi autori propituju ovaj stav ES-a - ponajprije zato što ga ES nikada nije potkrijepio empirijskim istraživanjem o odnosu potrošača prema različitim vrstama marketinških znakova, ${ }^{45}$ ali i zato što je prilično izvjesno da se odnos potrošača prema različitim vrstama marketinških znakova protokom vremena mijenja, ${ }^{46}$ što ES (i dalje) nije uzeo u obzir. Unatoč kritikama, ES je u nekoliko predmeta (koji su se odnosili na različite vrste nekonvencionalnih žigova) potvrdio svoj stav glede odnosa potrošača prema nekonvencionalnim znakovima. ${ }^{47}$ Ipak, u nekoliko predmeta (u kojima je imao priliku odlučivati o razlikovnosti znakova u kojima je sadržan oblik proizvoda) ES je potvrdio kako se znak (tj. oblik proizvoda) koji značajno odstupa od normi i običaja određenog tržišnog sektora, može smatrati inherentno distinktivnim (tj. razlikovnim per se) ${ }^{48}$ dok se u ostalim slučajevima razlikovnost (eventualno) može steći uporabom - što znači da podnositelj prijave mora dokazati kako su potrošači počeli doživljavati nekonvencionalni znak (npr. oblik ili boju proizvoda) kao razlikovni znak. ${ }^{49}$ Dokazivanje tzv. stečene razlikovnosti (osim što je skupo, dugotrajno i komplicirano) na razini EU-a poprilično je neizvjesno i nepredvidljivo - jer sudska praksa nije konzistentna u vezi s pitanjem područja na kojem se razlikovnost mora steći kada se želi registrirati žig EU-a. ${ }^{50}$

S druge strane, oblik proizvoda koji značajno odstupa od normi i običaja određenog tržišnog sektora (koji je, dakle, inherentno razlikovan) mora proći i “dodatne” apsolutne prepreke

43 Vidjeti, primjerice, odluku ES-a u spojenim predmetima Linde, Winward and Rado (C-53/01 - C-55/01) od 8. travnja 2003. godine, par. 42., 46. i 49 .

Linde, Winward and Rado, par. 48.

45 Vidjeti, primjerice: Kur, op. cit. u bilj. 11, str. 25.-26.

46 Primjerice, možemo s priličnom izvjesnošću tvrditi kako su se nekad nekonvencionalne, tj. neuobičajene i u praksi veoma rijetke vrste žigova (kao što su npr. zvučni žigovi) danas ustalile u praksi te ih mnogi potrošači zaista dovode u vezu s proizvođačima njima označenih proizvoda.

47 Primjerice, u predmetu OHIM v Erpo Möbelwerk (C-64/02) ES je ustanovio kako prosječni potrošač slogane doživljava prvenstveno kao marketinšku poruku, a ne kao indikator podrijetla proizvoda (odnosno, žig). Nadalje, prema tumačenju ESa, prosječan potrošač ni boje nije navikao doživljavati kao žig. Prema odluci ES-a u predmetu Libertel (C-104/01) na temelju nerazlikovnosti treba odbiti registraciju znaka koji se sastoji samo od boje per se. Iznimno, razlikovnima je moguće smatrati posebne i neuobičajene nijanse boja za označavanje određenih proizvoda ili usluga koje nije uobičajeno označavati bojama. Prema odluci ES-a u spojenim predmetima Procter\&Gamble (C-468 - 47201 P) potrošači nisu navikli doživljavati oblike proizvoda kao žig, a prema odluci ES-a u predmetu Mag Instrument Inc. v OHIM (C-136/02 P) razlikovnost znaka koji predstavlja oblik proizvoda teže je utvrditi nego razlikovni karakter figurativnog ili verbalnog znaka jer je doživljaj relevantne javnosti drugačiji nego u odnosu na verbalni ili figurativni znak.

48 Dakle, i znakovi koje potrošači nisu naviknuli doživljavati kao razlikovne, mogu biti inherentno (tj. sami po sebi) razlikovni, ako značajno odstupaju od znakova koji se upotrebljavaju u relevantnom tržišnom sektoru. Vidjeti, primjerice, odluke ES-a u povodu sljedećih predmeta: Deutsche SiSi-Werke v OHIM (C-173/04 P) od 12. siječnja 2006. godine, par. 31.; Mag Instrument v. OHIM (C-136/02 P) od 7. listopada 2004. godine, par. 31.; Joined Cases Henkel v. OHIM (C-456/01 P i 457/01 P) od 29. travnja 2004. godine, par. 39.

49 Takva se razlikovnost naziva i "stečena distinktivnost/razlikovnost". U SAD-u se koristi termin "secundary meaning" kojim se označava da je inherentno nerazlikovan znak na temelju uporabe stekao drugačije značenje - odnosno, od običnog promidžbenog znaka, postao je indikator porijekla, tj. razlikovni znak.

50 Primjerice, u predmetu Chocoladefrabiken Lindt \& Sprungli AG v OHIM (C - 98/11) ES je odstupio od prijašnjeg stajališta (prema kojem je razlikovnost morala biti stečena na području svih članica EU-a). 
da bi se mogao registrirati kao žig. Za takve je specifične oblike, norma prema kojoj se kao žig ne mogu registrirati oblici koji proizvodu daju značajnu vrijednost, (uglavnom) nesavladiva prepreka. Stoga se postavlja pitanje: koji se to oblici proizvoda (u praksi) mogu registrirati kao žig? Uobičajeni oblici - ne mogu - jer su opisni i/ili nedistinktivni. Specifični oblici - (uglavnom) ne mogu - jer proizvodu daju značajnu vrijednost. Dakle, koji su to oblici pronašli "sigurnu luku” u tom skučenom međuprostoru između uobičajenih (nerazlikovnih) oblika i posebnih (razlikovnih) oblika koji značajno utječu na vrijednost proizvoda? Na ovo ćemo pitanje pokušati dati odgovor u nastavku rada.

U nastavku poglavlja (tj. u dijelu 2.1. i dijelu 2.2.) ukratko ćemo prikazati dvije prvonavedene dodatne apsolutne prepreke za registraciju oblika proizvoda kao žiga, dok ćemo se u ostatku rada usredotočiti na treću prepreku - odnosno na oblik koji proizvodu daje značajnu vrijednost.

\subsection{OBLIK KOJI PROIZLAZI IZ PRIRODE PROIZVODA}

Kao što je već navedeno, prema članku 7. (1) (e) (i) Uredbe (EU) 2017/1001 i članku 4. (1) (e) (i) Direktive (EU) 2015/2436, kao žig nije moguće registrirati znak koji se isključivo sastoji od oblika koji proizlazi iz prirode samog proizvoda.

Ova prepreka uglavnom se shvaća kao oživotvorenje načela prema kojem se pravo žiga ne smije koristiti na način koji narušava pravičnu tržišnu utakmicu na određenom tržištu. ${ }^{51} \mathrm{U}$ praksi je dugo dominiralo stajalište prema kojem se navedena prepreka za registraciju žiga imala primjenjivati samo kada se kao žig namjeravalo registrirati oblik proizvoda, u situaciji gdje konkurenti nisu imali na raspolaganju druge oblike, za istu vrstu proizvoda. Naime, u takvoj bi situaciji, dodjeljivanjem isključivog žigovnog prava nad određenim oblikom proizvoda, konkurenti bili onemogućeni nuditi istu vrstu proizvoda (koju ne mogu ponuditi u drugačijem obliku) u neograničenom periodu - što bi u potpunosti onemogućilo tržišnu utakmicu na dotičnom tržišnom sektoru te bi (posljedično) značajno narušilo interese javnosti..$^{52} \mathrm{OHIM}$ (danas EUIPO) u svojim smjernicama za ispitivanje žigova navodi kako bi se na temelju ovog pravila trebala odbiti registracija tzv. prirodnih oblika - npr. oblika banane kao žiga za banane. ${ }^{53}$ Iako se, isprva, ova prepreka čini suvišnom (budući da se njezina funkcija može ostvariti i primjenom opće apsolutne prepreke za registraciju žigova, prema kojoj se kao žig ne mogu registrirati znakovi koji su opisni) treba naglasiti kako se opisni znakovi ipak mogu registrirati kao žig, ako su postali razlikovni. Dakle, opisnost je tzv. prevladiva prepreka za registraciju žiga. ${ }^{54} \mathrm{~S}$ druge strane, znakovi koji predstavljaju prirodan oblik proizvoda (osim što su opisni) istovremeno su podvrgnuti i prepreci za registraciju iz članaka 4. (1) (e) (i) Direktive (EU)

51 Tako: Kur, op. cit. u bilj. 11, str. 14.

52 Loc. cit.

53 Tako i: EUIPO, Examination Guidelines, Part B, Sec (4), Chapter 6 (2), dostupno na:https://guidelines.eui po.europa. eu/1803468/1786987/trade-mark-guidelines/2-shape-or-other-characteristics-resulting-from-the-nature-of - the-goods. Pristupljeno 2. svibnja 2020.

54 Npr. ako prosječan potrošač znak ne doživljava kao opisan, već kao indikator porijekla proizvoda, kao npr. u predmetu Matratzen Concord AG v Hukla Germany SA (C-421/04) od 9. ožujka 2006. godine. 
2015/2436 (odnosno, iz članka 7. (1) (e) (i) Uredbe (EU) 2017/1001) koja je neprevladiva te se, primjerice, oblik banane ne bi mogao registrirati kao žig za banane čak ni kada bi, na temelju uporabe, postao distinktivan na određenom području - što je, u praksi, ipak teško zamislivo.

Treba naglasiti da je donošenjem odluke u predmetu Hauck, ${ }^{55}$ ES proširio polje primjene navedene odredbe. Naime, ES je zaključio kako zbog dotadašnjeg veoma uskog tumačenja navedene odredbe ona ima ograničenu mogućnost primjene u praksi - budući da se može primijeniti samo na tzv. prirodne oblike (koji neposredno proizlaze iz oblika proizvoda i koje u prirodi nije moguće pronaći u bitno drugačijem obliku) te na tzv. zakonske oblike (koji se javljaju kada je određen oblik proizvoda definiran pravnim normama od kojih nije dopušteno odstupanje ili je dopušteno tek neznatno odstupanje). U oba slučaja riječ je o oblicima koji su opisni i/ili inherentno nerazlikovni te je prilično izvjesno da ni uporabom neće postati razlikovni. Kako bi proširio mogućnost primjene navedene odredbe, ES je ocijenio da sintagmu "oblik koji proizlazi iz prirode proizvoda" treba shvatiti kao "oblik koji sadrži bitne karakteristike proizvoda koje su svojstvene osnovnoj (generičkoj) funkciji ili funkcijama proizvoda” ${ }^{56}$ Prevedeno na jezik prakse, ovo bi značilo sljedeće: ako oblik ima neke dodatne karakteristike (koje ne proizlaze iz prirode proizvoda) svejedno se neće moći registrirati kao žig, ako istovremeno sadrži i bitne karakteristike proizvoda (koje proizlaze iz prirode proizvoda ili su svojstvene osnovnoj, tj. generičkoj funkciji dotičnog proizvoda). Primjerice, dječja sjedalica koja se na tržištu nudila pod nazivom Tripp Trapp (čiji je oblik bio predmet spora u predmetu Hauck) zaista ima poseban oblik koji se može mijenjati kako bi se stolica prilagodila uzrastu djeteta. Međutim, znak koji se sastoji isključivo od oblika navedene stolice, svejedno se ne može registrirati kao žig - zato što u sebi sadrži bitne karakteristike stolice. To što ovaj znak (oblik stolice) ima i neka dodatna obilježja (koja ne proizlaze izravno iz prirode stolice i nisu svojstvena generičkoj funkciji stolice) nije dostatan razlog da se pravilo koje priječi mogućnost njegove registracije kao žiga ne bi primijenilo. Naime, ES smatra da bi monopoliziranjem takvih esencijalnih karakteristika proizvoda (preko oblikovnih žigova) jedan konkurent mogao steći neopravdanu prednost pred ostalim konkurentima te bi takva postupanja trebalo onemogućiti. ${ }^{57} \mathrm{Ne}$ možemo se oteti dojmu da je ovako širokim tumačenjem, normu koja priječi mogućnost registracije žiga (kada je riječ o oblicima koji proizlaze iz oblika proizvoda), ES učinio prilično nejasnom i nepredvidljivom te se izgubila jasna granica između ovog pravila i pravila iz iduće alineje - prema kojem kao žig nije moguće registrirati oblik proizvoda koji ima tehničku funkciju.

\subsection{OBLIK PROIZVODA KOJI IMA TEHNIČKU FUNKCIJU}

Kao što je već navedeno, prema članku 7. (1) (e) (ii) Uredbe (EU) 2017/1001 i članku 4. (1) (e) (ii) Direktive (EU) 2015/2436, kao žig nije moguće registrirati znak koji se isključivo sastoji od oblika koji je nužan za ostvarivanje tehničkog rezultata. U predmetu Philips ${ }^{58}$ ES je istaknuo kako je cilj navedene odredbe spriječiti mogućnost da se kao žigovi registriraju oblici čija bitna

\footnotetext{
55 Hauck GmbH \& Co. KG v Stokke A/S and Others (C-205/13) od 18. rujna 2014. godine.

56 Hauck, par. 44.

57 Hauck, par. 26.

58 Oznaka presude navedena je supra, u bilj. 14.
} 
obilježja imaju tehničku funkciju, uz obrazloženje da bi isključivo pravo žiga nad takvim oblicima ili u potpunosti onemogućilo konkurente da na tržištu nude proizvode koji sadrže takvu funkciju ili bi ograničilo njihovu mogućnost izbora glede načina na koji će dotičnu tehničku funkciju inkorporirati u svojim proizvodima. ${ }^{59}$

U istom je predmetu (Philips, op. a.) ES istaknuo da se ova odredba primjenjuje i kada se isti tehnički rezultat (tj. ista funkcija) može ostvariti na drugačiji način - tj. primjenom drugih oblika. Naime, glede ovog pitanja, nacionalni su sudovi zemalja članica EU-a zauzimali različita stajališta. Primjerice, okružni sud na području Stockholma zaključio je kako je žig Philipsa (koji prikazuje vanjski izgled proizvoda, tj. električni brijač s "tri glave") valjan - jer se isti rezultat koji se ovim oblikom električnog brijača ostvaruje, može ostvariti i primjenom drugih oblika - tj. električnim brijačima drugačijeg izgleda. ${ }^{60}$ Suprotno tome, žalbeni sud na području Velike Britanije, smatrao je da istovjetni žig Philipsa nije valjan, zato što u sebi sadrži oblik proizvoda koji ima tehničku funkciju - bez obzira na to što se istovjetna funkcija može ostvariti i primjenom drugačijih oblika. ${ }^{61} \mathrm{U}$ povodu tzv. zahtjeva za prethodno odlučivanje koji je podnio britanski sud, ES je ocijenio kako prema izričaju odredbe koja je sadržana u članku 3. (1) (e) (ii) Direktive 89/104/EEZ ${ }^{62}$ ništa ne ukazuje na to ta bi registarska tijela trebala provjeravati je li funkciju koja se ostvaruje oblikom koji se želi registrirati kao žig, moguće ostvariti na drugi način, tj. drugim oblikom. Nadalje, prema stavu ES-a, navedena odredba ima za cilj spriječiti pojedince da uporabom žigova stječu isključiva prava nad tehničkim rješenjima u neograničenom trajanju. Stoga je ova odredba "nepremostiva" te se njezina primjena ne može izbjeći uz obrazloženje da se isti tehnički rezultat može ostvariti primjenom drugačijih oblika. ${ }^{63}$

Vodeći se sličnim obrazloženjem, odnosno ratiom odredbe o nemogućnosti stjecanja žiga nad znakom (tj. oblikom) koji ima tehničku funkciju, ES je ocijenio da je valjana odluka Općeg suda kojom je potvrdio odluku Žalbenog vijeća OHIM-a kojom je poništen žig EU-a (tada žig Zajednice) koji je na području EU-a imao Lego nad oblikom lego-kocke. ${ }^{64} \mathrm{U}$ tom je predmetu ES izričito istaknuo da je jedna od svrha odredbe o nemogućnosti registracije žiga (za oblike koji imaju tehničku funkciju) spriječiti produljivanje trajanja patentnih prava po njihovu isteku. ${ }^{65}$ Ovime je ES potvrdio da patent i pravo žiga ne mogu koegzistirati (niti paralelno niti konsekventno) nad istim objektom zaštite - tj. nad oblikom koji ima tehničku funkciju. ${ }^{66}$

Iako (prema najširem tumačenju) svaki oblik proizvoda može imati nekakvu funkciju - iz čega bi proizlazio zaključak da se nijedan oblik proizvoda ne može registrirati kao žig - ovo je "ublaženo" činjenicom da se kao žig ne može registrirati samo znak koji se isključivo (što pre-

\footnotetext{
59 Philips, par. 79.

60 Ide Line v Phillips Electronics (Švedska, 1997) - prema: Cornish; Llewelyne; Aplin, op. cit. u bilj. 14, str. 730.

61 Philips Electronics v Remington (UK, 1999) - prema: loc. cit.

62 Danas je ova odredba u gotovo istovjetnom obliku sadržana u članku 4. (1) (e) (ii) Direktive (EU) 2015/2436.

63 Philips, par. 81.-84.

64 Lego Juris v. OHIM (C-48/09) od 14. rujna 2009. godine, par 54 et seq.

65 Lego Juris, par. 45

66 Ovo vrijedi uvijek kada je određen proizvod mogao biti zaštićen patentom - neovisno o tome je li pravo na zaštitu de facto ostvareno ili ne. Dakle - tehnička rješenja (izumi) mogu se štititi samo patentom, u strogo ograničenom periodu, dok zaštita izuma žigovima nije dopuštena - u vezi s tim pitanjem suglasne su pravna praksa i teorija.
} 
ma sudskoj praksi znači u potpunosti ili u značajnom dijelu ${ }^{67}$ ) sastoji od oblika koji je nužan za ostvarivanje tehničke funkcije - neovisno o činjenici može li se dotična funkcija ostvariti drugim oblicima. Prevedeno u jezik prakse - oblik lego-kocke ne može se štititi kao oblikovni žig čak ni ako se osnovnom obliku lego-kocke dodaju dodatna obilježja (primjerice, određena boja) koja ne utječu bitno na funkciju lego-kocke (tj. na mogućnost modularnog spajanja). Ovo ne mijenja ni činjenica da se ista funkcija (modularno spajanje dijelova igračaka) može ostvariti i na drugi način - npr. ispupčenjima u obliku trokuta, umjesto cilindričnim ispupčenjima. ${ }^{68}$

\section{OBLIK KOJI ZNAČAJNO DETERMINIRA VRIJEDNOST PROIZVODA KAO APSOLUTNA PREPREKA ZA REGISTRACIJU ŽIGA}

\subsection{IZVORIŠTE I RATIO LEGIS}

U literaturi se redovito ističe kako odredba prema kojoj se oblik koji proizvodu daje značajnu vrijednost ne može registrirati kao žig, potječe iz nekadašnjeg beneluškog Zakona o žigu iz 1975. godine. ${ }^{69} \mathrm{U}$ preambuli navedenog Zakona, beneluški je zakonodavac izričito naveo kako je cilj ove odredbe postaviti određena ograničenja kada je riječ o mogućnosti da pravo žiga postoji paralelno s autorskim pravom ili pravom industrijskog dizajna. ${ }^{70}$ Nadalje, beneluški je zakonodavac istaknuo kako oblik neizbježno proizvodu daje određenu vrijednost, odnosno privlačnost. Kada se uzme u obzir priroda proizvoda, ta privlačnost može biti od ključnog značaja. Stoga se odabrani oblik proizvoda neće moći štititi kao žig. Primjerice, umjetnički izričaj (tj. oblik) u kojem je izrađena kristalna čaša ne može se štititi kao žig - budući da ključna vrijednost tog proizvoda ne proizlazi samo iz materijala od kojeg je čaša napravljena, već također (a možda i ponajviše) iz privlačnosti njezina oblika. S druge strane, kada je riječ o prehrambenim proizvodima (npr. čokoladnim proizvodima), oni se mogu prodavati u privlačnom obliku koji nema stvarni utjecaj na vrijednost u njima utjelovljenih proizvoda. Takav oblik može, u određenim okolnostima, djelovati kao razlikovni znak te se tada može registrirati i štititi kao žig - bez obzira na činjenicu što se paralelno može štititi autorskim pravom ili pravom industrijskog dizajna. ${ }^{71}$

Iz navedenog obrazloženja beneluškog zakonodavca proizlazi kako je cilj analizirane odredbe bio: u određenim (ali ne svim) situacijama spriječiti mogućnost preklapanja žigovnog prava

67 Lego Juris, par. 52: “(...) the presence of one or more minor arbitrary elements in a three-dimensional sign, all of whose essential characteristics are dictated by the technical solution to which that sign gives effect, does not alter the conclusion that the sign consists exclusively of the shape of goods which is necessary to obtain a technical result." ES je ocijenio da boja lego-kocke nije bitan element trodimenzionalnog znaka koji prikazuje lego-kocku crvene boje. Stoga je zaključio da je riječ o trodimenzionalnom znaku koji se isključivo sastoji od oblika proizvoda, što znači da je ispunjen uvjet za primjenu dodatnih apsolutnih prepreka za registraciju žiga EZ-a iz članka 7. (1) (e) Uredbe o žigu EZ-a.

68 Lego Juris, par. 83.

69 Primjerice: Gielen, op. cit. u bilj. 17, str. 164.; Max Planck Institute, op. cit. u bilj. 25, par. 2. 32.; Rosati, op. cit. u bilj. 10, str. 4.; Kur, op. cit. u bilj. 17, str. 8.

70 Prema: Gielen, op. cit. u bilj. 17, str. 165

71 Loc. cit. 
s autorskim pravom i pravom industrijskog dizajna. Dakle, i prema beneluškom Zakonu o žigu iz 1975. godine, preklapanja između žigovnog i autorskog prava/prava industrijskog dizajna, načelno su bila moguća - osim, u iznimnim situacijama, gdje je oblik proizvoda značajno utjecao na vrijednost proizvoda - što je (u praksi) uvelike ovisilo o prirodi (tj. vrsti) proizvoda na kojem je dotični oblik bio primijenjen. Zakonodavac je očito smatrao kako nije opravdano omogućiti stjecanje isključivih prava, neograničenog trajanja (primjenom žigova) nad oblicima koji proizvodu daju značajnu vrijednost. Takve je oblike moguće štititi autorskim pravima i/ili pravima industrijskog dizajna, ali u ograničenom periodu. S druge strane, ako je riječ o obliku koji ne utječe značajno na vrijednost proizvoda (što ponajprije ovisi o tome iz kojeg tržišnog sektora proizvod dolazi) - oblik se može štititi u neograničenom periodu (primjenom žigova), neovisno o činjenici što se paralelno može štititi i vremenski ograničenim pravima intelektualnog vlasništva - tj. autorskim pravom i industrijskim dizajnom. Iz ovoga možemo iščitati kako je ultimativni cilj beneluškog zakonodavca bio osigurati pravičnu tržišnu utakmicu - odnosno, onemogućiti stjecanje isključivih subjektivnih prava koja bi jednom tržišnom konkurentu osigurala prednost pred ostalim tržišnim konkurentima u neograničenom trajanju - što je, $u$ konačnici, protivno interesima potrošača (tj. cjelokupne javnosti).

Treba imati na umu da je ovo pravilo u beneluški Zakon o žigu uvedeno prije nego što je europski zakonodavac odlučio harmonizirati žigovno pravo na području EU-a te prije nego što je Europski sud svojom praksom uspostavio načelo prema kojem oblik proizvoda (kao i brojne druge vrste neuobičajenih znakova) razlikovnost, u pravilu, mogu steći samo uporabom - čime je de facto značajno otežana mogućnost registracije oblikovnih žigova na području EU-a. Treba istaknuti kako, u razdoblju kada je usvajan beneluški Zakon o žigu iz 1975. godine, registarsko tijelo nadležno za područje Beneluxa, nije bilo ovlašteno ex officio ispitivati materijalne, već samo formalne pretpostavke za registraciju žiga, a presumpcija o oblicima proizvoda kao nerazlikovnim znakovima još nije bila uspostavljena. ${ }^{72} \mathrm{U}$ tom je razdoblju, dakle, oblik proizvoda bilo veoma jednostavno registrirati kao žig. Stoga, smatramo kako je beneluški zakonodavac učinio (za ono vrijeme) veoma značajan iskorak glede pitanja zaštite tržišne konkurencije koju je bilo moguće dugoročno narušiti različitim makinacijama unutar sustava žigovnog prava.

Iz današnje perspektive, neprimjenjivim se čini obrazloženje beneluškog zakonodavca prema kojem mogućnost zaštite oblika proizvoda kao žiga uvelike ovisi o sektoru iz kojeg dotični proizvod dolazi. Prema obrazloženju sadržanom u nekadašnjem beneluškom Zakona o žigu, u nekim tržišnim sektorima (kao što je, primjerice, sektor prehrambenih proizvoda) oblik proizvoda ne utječe značajno na vrijednost proizvoda - budući da na odluku potrošača o kupnji određenog proizvoda (navodno) mnogo veći utjecaj imaju ostale karakteristike proizvoda (npr. okus). U današnje vrijeme sensory brandinga, gdje proizvođači nastoje utjecati na sva osjetila kupaca i gdje estetika proizvoda uvelike determinira odabir kupaca, gotovo je nemoguće zamisliti tržišni sektor gdje vanjski izgled proizvoda (što uključuje i oblik proizvoda) ne bi imao utjecaja na kupca - iako je, u praksi, katkad teško razlučiti je li taj utjecaj prevladavajuć ili ne. ${ }^{73}$

Kao što je navedeno, najraniji europski izvori iz područja žigovnog prava (Direktiva 89/104 i Uredba br. 40/94) nisu sadržavali obrazloženje o tome zašto neki znakovi (tj. oblici), u odre-

72 Prema: Kur, op. cit. u bilj. 17, str. 11.

73 U nastavku rada prikazat ćemo različita stajališta beneluških sudova u vezi s pitanjem utječe li oblik grickalice značajno na vrijednost grickalice. 
đenim situacijama, trebaju biti isključeni od mogućnosti zaštite u okviru žigovnog prava, a ne sadrže ga ni danas važeći propisi iz područja žigovnog prava EU-a (Direktiva EU 2015/2436 i Uredba EU 2017/1001). ${ }^{74}$ Stoga, pravi razlog ovog ograničenja nije jednostavno uočiti. ${ }^{75} \mathrm{U}$ teoriji se, kao mogući razlozi, redovito ističu dva obrazloženja:

a) sprječavanje neopravdanog produžavanja vremenski ograničenih prava intelektualnog vlasništva, primjenom žigova;

b) zaštita konkurencije - budući da bi jedan konkurent, stjecanjem isključivih prava nad oblikom proizvoda, u neograničenom trajanju, stekao neopravdanu prednost pred ostalim konkurentima. ${ }^{76}$

Relevantne sudske odluke pozivaju se na oba ovdje navedena obrazloženja, s time da se drugo obrazloženje redovito navodi kao posljedica prvog obrazloženja. ${ }^{77}$

U odluci ES-a koja se danas smatra najanalitičnijom ocjenom odredbe o značajnoj vrijednosti oblika proizvoda kao prepreci za registraciju žiga (tj. u odluci ES-a u predmetu Hauck ${ }^{78}$ ) Europski sud istaknuo je kako je cilj navedene odredbe:

“(...) spriječiti mogućnost stjecanja isključivog i trajnog prava (registracijom žiga), čime se de facto ostvaruje neograničeno produljenje trajanja drugih prava intelektualnoga vlasništva koje je EU zakonodavac izričito vremenski ograničio." ${ }^{\text {"9 }}$

To da je ratio legis ovdje analiziranog pravila izbjegavanje neopravdanog produljenja vremenski ograničenih prava intelektualnog vlasništva nije iznenađujuće, s obzirom na povijesno podrijetlo, odnosno izvor navedenog pravila. Međutim, dok nekada istodobna zaštita istog objekta različitim pravima intelektualnog vlasništva nije bila moguća prema određenim nacionalnim jurisdikcijama, prema pozitivnopravnim rješenjima na području EU-a nije zabranjeno da se oblici (ili druge karakteristike) proizvoda istovremeno štite različitim pravima intelektualnog vlasništva. Stoga, nema prepreke da se oblik koji je zaštićen ili koji je prethodno bio zaštićen sada već isteklim autorskim pravom ili pravom industrijskog dizajna, registrira kao žig. ${ }^{80}$ Treba napomenuti da su preklapanja među pravima intelektualnog vlasništva posljedica progresivnog širenja opsega zaštite različitih prava intelektualnog vlasništva, izvan njihova izvornog okvira te ne predstavljaju nužno problem - posebice ako se uzme u obzir da objekt koji je predmet zaštite može imati "više naličja" (odnosno više različitih aspekata), ali i s obzirom na različitu svrhu koja se svakim od tih prava želi ostvariti, kao i s obzirom na različite zaštitne mjere koje pripadaju svakom od eventualnih paralelnih prava intelektualnoga vlasništva. ${ }^{81}$ Unatoč činjenici da su (prema pozitivnopravnoj regulativi) na području EU-a preklapanja između različitih prava intelektualnog vlasništva (izuzevši patente) moguća, prijašnje autor-

\footnotetext{
74 Vidjeti supra-bilj. 36.

75 Slično i: Rosati, op. cit. u bilj. 10, str. 5.

76 Loc. cit.

77 Loc. cit.

78 Oznaka odluke ES-a u predmetu Hauck navedena je supra, pod bilj. 55.

79 Hauck, par. 19.

80 Tako i: Rosati, op. cit. u bilj. 10, str. 7. Ovo je potvrdio i ES, u recentnoj odluci u povodu predmeta Gömböc Kutató, Szolgáltató és Kereskedelmi Kft. v Szellemi Tulajdon Nemzeti Hivatala (C-237/19) od 23. travnja 2020. (dalje u tekstu Gömböc), par. 53. 
sko pravo ili pravo industrijskog dizajna u praksi ipak može predstavljati svojevrsnu "otegotnu okolnost” u postupku registracije žiga. Naime, takvo pravo može ukazivati da je potrebno primijeniti povećanu pozornost u postupku ocjene određenih apsolutnih prepreka za registraciju žiga - kao što je značajan utjecaj oblika proizvoda na vrijednost proizvoda. ${ }^{82}$

Prema nekim autorima, ${ }^{83}$ drugi rationale (tj. osiguranje pravične tržišne konkurencije) čini se nešto slabijim opravdanjem kada je riječ o odredbi koja sprječava mogućnost da se kao žig registriraju oblici koji značajno utječu na vrijednost proizvoda, u odnosu na odredbe kojima se priječi mogućnost da se kao žig registriraju oblici koji imaju tehničku funkciju ili proizlaze iz prirode proizvoda. Ipak, u predmetu Philips, ${ }^{84} \mathrm{ES}$ je istaknuo kako je cilj svih odredbi sadržanih u članku 3. (1) (e) Direktive 89/104/EEZ ${ }^{85}$ onemogućiti da se s pomoću sustava žigovnog prava dodjeljuju isključiva subjektivna prava (kao svojevrsni monopoli) nad tehničkim rješenjima ili nad funkcionalnim obilježjima proizvoda za koje je izvjesno da će ih potrošači potraživati i u proizvodima konkurenata ${ }^{86}$ - odnosno, nad oblicima koji su potrošačima privlačni zbog bilo kojeg razloga - op. a. Dakle, prema stavu ES-a izraženom u predmetu Philips, ova je odredba u cjelini (odnosno, glede svih triju apsolutnih prepreka koje su u njoj sadržane) usmjerena na suzbijanje nepravičnog ograničavanja tržišnog natjecanja. ${ }^{87}$ Naknadno je, u predmetu Bang\&Olufsen, ${ }^{88}$ Opći sud i izričito potvrdio da posljednja alineja navedene odredbe (kojom je predviđeno da se oblici koji značajno determiniraju vrijednost proizvoda ne mogu registrirati kao žig) ima za cilj osigurati pravičnu tržišnu utakmicu. ${ }^{89}$ Ovaj rationale istaknuo je i AG Szpunar u prvom mišljenju koje je iznio u predmetu Louboutin. ${ }^{90}$ Prema njegovu mišljenju cilj ove odredbe očituje se u sprječavanju monopoliziranja onih vanjskih obilježja proizvoda koja su od presudnog značenja za njihov tržišni uspjeh, kako bi se spriječilo da se zaštita koja pripada nositelju žiga koristi kao neopravdana prednost na tržištu - tj. kao prednost koja ne proizlazi iz konkurencije utemeljene na cijeni i kvaliteti. U konačnici, na ovaj se rationale izričito i jasno pozvao ES, u recentnoj odluci u povodu predmeta Gömböc: ${ }^{91}$

“(...) primjena razloga za odbijanje registracije (koji je predmet analize u ovom radu - op. a.) počiva na objektivnom ispitivanju koje je namijenjeno dokazivanju toga da predmetni oblik zbog svojih vlastitih značajki toliko značajno utječe na privlačnost proizvoda da bi zadržavanje

82 Ibidem, str. 8 .

83 Npr. prema Rosati (loc. cit.). Gielen (op. cit. u bilj. 17, str. 167.) ide i "korak dalje" te ističe kako smatra da ovog rationalea kod odredbe iz članka 4 (1) (e) Direktive (EU) 2015/2436 i Uredbe (EU) 2017/1001 uopće nema - jer ne vidi opravdan razlog zbog kojeg bi se nekome moralo dopustiti da koristi vanjski izgled (tj. dizajn) proizvoda koji je konkurent osmislio. S druge strane, Kur (op. cit. u bilj. 17, str. 22) ističe da je upravo ovaj rationale ključan za ispravnu primjenu ovih pravila.

84 Oznaka odluke ES-a u predmetu Philips navedena je supra - pod bilj. 14.

85 Koji su danas, u gotovo istovjetnom obliku, sadržani u članku 4. (1) (e) Direktive (EU) 2015/2436.

86 Philips, par. 78

87 Prema tumačenju Gielena (op. cit. u bilj. 17, str. 167.) obrazloženje ES-a iz predmeta Philips, ne odnosi se na treću dodatnu apsolutnu prepreku za oblikovne žigove, već samo na prve dvije.

88 Bang \& Olufsen v OHIM (T-508/08) od 6. listopada 2011. godine.

89 Bang \& Olufsen, par. 66.

90 Vidjeti: Opinion of Advocate General Szpunar in Christian Louboutin and Christian Louboutin Sas v van Haren Schoenen BV (dalje u tekstu: Louboutin AG1) od 22. lipnja 2017. godine, par. 69. http://curia.europa.eu/juris/document/document. jsf?text=\&docid=192069\&pageIndex=0\&doclang=EN\&mode=req\&dir=\&occ=first\&part=1\&cid=1682285. Pristupljeno 7. travnja 2020. Riječ je o mišljenju koje je AG Szpunar dao u povodu predmeta Christian Louboutin, Christian Louboutin SAS v Van Haren Schoenen BV (C-163/16) od 12. lipnja 2018. godine. 
prednosti tog oblika samo za jednog poduzetnika narušilo uvjete tržišnog natjecanja na predmetnom tržištu." 92

Možemo zaključiti kako u osnovi oba analizirana rationalea "leži" zaštita javnog interesa" - koju, stoga, smatramo ultimativnim rationaleom odredbe o značajnoj vrijednosti oblika proizvoda kao apsolutnoj prepreci za registraciju žiga. ${ }^{94}$

\subsection{OPSEG PRIMJENE}

U dijelu 3.2.1. prikazat ćemo kako bi, prema relevantnoj sudskoj praksi, trebalo tumačiti pojam “oblik" iz članka 4. (1) (e) (iii) Direktive (EU) 2015/2436 i članka 7. (1) (e) (iii) Uredbe (EU) 2017/1001, dok ćemo u dijelu 3.2.2. pojasniti je li pri posljednjoj reviziji žigovnog prava na području EU-a, opseg primjene ovdje analiziranog pravila zaista proširen i na ostale karakteristike proizvoda ili je navedenom revizijom tek (na jasan i nedvosmislen način) u Direktivu i Uredbu implementirano obrazloženje ES-a prema kojem pojam "oblik" (u kontekstu ovdje analiziranog pravila) treba tumačiti u najširem značenju - koje obuhvaća i ostale vanjske karakteristike proizvoda.

U dijelu 3.2.3. obrazložit ćemo što (prema relevantnoj sudskoj praksi) znači sintagma “značajan utjecaj na vrijednost proizvoda".

\subsubsection{ZNAČENJE POJMA “OBLIK PROIZVODA”}

Treba naglasiti da su glede tumačenja pojma "oblik proizvoda” u praksi moguće dvije različite situacije.

Kao prvo, moguće je da u prijavi za registraciju žiga podnositelj ne navede izričito da je grafički znak koji želi registrirati kao žig zapravo dvodimenzionalni prikaz inače trodimenzionalnog proizvoda. ${ }^{95}$ Pravni teoretičari ${ }^{96}$ suglasni su da u ovoj situaciji podnositelju prijave ne bi smjelo biti dopušteno da zaobiđe pravila koja se odnose na oblikovne (3D) žigove u kojima je sadržan oblik proizvoda. ${ }^{97}$ Ovo je potvrdio i ES, koji je u predmetu August Storck v OHIM ${ }^{98}$

92 Gömböc, par. 40.

93 Subjektivna prava intelektualnog vlasništva (izuzevši žig) vremenski su ograničena kako bi se uspostavio balans između pobude za stvaranjem (koja se želi osigurati kreativnim/inovativnim pojedincima) i interesa društva kao cjeline - koje želi "uživati” u što bogatijoj javnoj domeni. Ultimativni cilj pravične tržišne utakmice očituje se u zaštiti interesa potrošača (tj. javnosti) - kojima treba osigurati izbor između različitih predmeta iste vrste po različitim cijenama kad god je to moguće. Kako se odredbom o nemogućnosti registracije žiga (kada je riječ o oblicima koji značajno determiniraju vrijednost proizvoda) želi spriječiti neopravdano produljenje vremenski ograničenih prava intelektualnog vlasništva (autorskog prava i/ili prava industrijskog dizajna) te osigurati pravičnu tržišnu utakmicu, slijedi da je ultimativni ratio ove odredbe zaštititi interese javnosti.

Slično ističe i Rosati (op. cit. u bilj. 10, str. 9.).

ovoj problematici, vidjeti više u: Gangjee, D. S., Paying the Price for Admission: Non-Traditional Marks across Registration and Enforcement, objavljeno u: Calboli, I.; Senftleben, M. (ur), The Protection of non-trdaitional marks: critical perspectives, Oxford University Press, Oxford, UK, 2018., str. 10.-15. Ibidem, str. 15.; Gielen, op. cit. u bilj. 17, str. 165.

Treba naglasiti da postoje i oblikovni (3D) žigovi koji ne predstavljaju oblik proizvoda. Ovakvi se žigovi veoma često koriste $u$ automobilskoj industriji - primjerice, trodimenzionalni prikaz jaguara, "Mercedesova zvijezda" i sl. Na ove se žigove ne primjenjuju dodatne prepreke koje je europski zakonodavac propisao za slučajeve kada se kao žig želi registrirati oblik koji je ujedno oblik proizvoda. 
izričito naveo da se sudska praksa koja se odnosi na trodimenzionalne znakove koji predstavljaju izgled proizvoda:

“(...) ima primijeniti i u slučajevima gdje je (...) podnesena prijava za registraciju figurativnog znaka koji je de facto dvodimenzionalni prikaz proizvoda. U ovoj se situaciji, naime, žig ne bi sastojao od znaka koji nije povezan s izgledom proizvoda koji se njime označava"99 - stoga se takvom znaku ne može pružiti zaštita u okviru žigovnog prava (op. a.).

Kao drugo, postavlja se pitanje primjenjuju li se dodatne apsolutne prepreke za registraciju žigova koji predstavljaju izgled proizvoda i na dvodimenzionalne znakove koji ne predstavljaju izgled (tj. oblik) proizvoda, već predstavljaju određeni vanjski segment, odnosno određenu karakteristiku proizvoda - kao što je, primjerice, dvodimenzionalni uzorak koji je primijenjen na proizvodu - što je čest slučaj u tekstilnoj industriji. Glede odgovora na ovo pitanje pravni se teoretičari razilaze. ${ }^{100}$ Međutim, Opći sud ističe da:

“(...) članak 7. (1) (e) ne definira što obuhvaća pojam oblik, tj. ne specificira koje bi to znakove trebalo smatrati oblicima. Taj članak, dakle, ne pravi razliku između dvodimenzionalnih oblika, trodimenzionalnih oblika i dvodimenzionalnih oblika koji prikazuju trodimenzionalne oblike. Stoga, treba smatrati da se članak 7. (1) (e) Uredbe o žigu EZ br. 207/2009 može primijeniti i na dvodimenzionalne oblike." 101

Ovo je stajalište ES izričito potvrdio u predmetu Louis Vuitton ${ }^{102}$ gdje je istaknuo da:

“(...) ono što vrijedi za trodimenzionalne žigove koji se sastoje od oblika proizvoda, vrijedi i za dvodimenzionalne (figurativne) žigove koji se sastoje od izgleda proizvoda. Naime, i ovdje je riječ o znakovima koji nisu neovisni od vanjskog izgleda njime označenih proizvoda."103 da:

Ovo je ES, ponešto drukčije izrečeno, potvrdio i u predmetu Louboutin, ${ }^{104}$ gdje je istaknuo

“(...) u kontekstu žigovnog prava, pojam 'oblik' treba općenito shvatiti na način da označava sve linije i obrise koji prostorno ograničavaju proizvod."105

Ipak, u predmetu Textilis, ${ }^{106}$ ES je istaknuo da članak 7. (1) (e) (iii) Uredbe (EU) 207/2009107 treba tumačiti na način da se:

“znak (...) koji se sastoji od dvodimenzionalnih dekorativnih motiva i koji se stavlja na proizvode poput tkanine ili papira, ne 'sastoji isključivo od oblika' u smislu te odredbe."108

\footnotetext{
99 August Storck v OHIM, par. 29.

100 Vidjeti, primjerice, razilaženja Gielena i Verkadea, koja Gielen (op. cit. u bilj. 17.) opisuje na str. 165.-166.

101 Opći sud, Yoshida Metal Industry v OHIM (T-331/10) od 8. svibnja 2012. godine.

102 Louis Vuitton Malletier v OHIM (C-97/12) od 15. svibnja 2014. godine.

103 Louis Vuitton Malletier v OHIM, par. 53.

104 Oznaka Odluke ES-a u predmetu Louboutin već je navedena supra - u bilj. 90.

105 Louboutin, par. 21.

106 Textilis Ltd, Ozgur Keskin v. protiv Svenskt Tenn AB (C-21/18) od 14. ožujka 2019. godine.

107 Koji je danas, u gotovo istovjetnom obliku, sadržan u članku 7. (1) (e) (iii) Uredbe 2017/1001.

108 Textilis, par. 48
} 
Dakle, prema stavu ES-a (iz predmeta Textilis) kada se kao žig želi registrirati figurativni znak koji se sastoji od dekorativnih uzoraka primijenjenih na proizvodima kao što su papir ili tkanina, treba smatrati da nisu ispunjeni uvjeti za primjenu prepreke za registraciju žiga iz članka 7. (1) (e) (iii) Uredbe (EU) 207/2009 zato što se ne može smatrati da je riječ o znaku koji se isključivo sastoji od oblika proizvoda. ${ }^{109}$

Iz analizirane prakse čini se kako je teško predvidjeti hoće li ES određeni znak smatrati oblikom ili ne. Nadalje, teško je predvidjeti hoće li ES ocijeniti da se određeni znak isključivo sastoji od oblika proizvoda ili ne. ${ }^{110}$ Ovo potvrđuje tezu da je učinak ovdje analizirana prepreke za registraciju žiga prilično nepredvidljiv - što može izazvati brojne probleme u praksi.

\subsubsection{OSTALA OBILJEŽJA PROIZVODA}

Posljednjom revizijom žigovnog prava EU-a iz 2015 godine ${ }^{111}$ u tekst odredbi kojima su predviđene dodatne apsolutne prepreke za registraciju žiga (u slučajevima kada se kao žig želi registrirati oblik proizvoda) uz pojam "oblik proizvoda" dodana je i sintagma "ostala obilježja proizvoda".

Naime, prije revizije iz 2015. godine, neki su pravni teoretičari pozivali europskog zakonodavca da dodatne prepreke za apsolutnu registraciju oblikovnih žigova proširi i na određene nekonvencionalne žigove - odnosno, na žigove koji se sastoje od vanjskih obilježja proizvoda. Smatrali su da, i posredstvom takvih žigova, njihovi nositelji mogu steći svojevrsni monopol (neograničenog trajanja) nad određenim segmentima proizvoda - čime se, također, ograničava slobodno tržišno natjecanje. ${ }^{112}$ Shodno tome, dodavanje sintagme "i ostala obilježja" u tekst odredbi kojima su regulirane dodatne apsolutne prepreke za registraciju žigova, dio autora protumačio je kao čin proširenja opsega primjene navedenih odredbi. ${ }^{113}$ Neki su se autori zapitali mogu li se nova (proširena) legislativna rješenja primijeniti retroaktivno - odnosno, mogu li se (pozivanjem na proširenu normu) poništiti registrirani žigovi koji se isključivo sastoje od vanjskog obilježja proizvoda (kao što je boja ili tekstura). ${ }^{114}$ Ovo je pitanje postalo posebice aktualno nakon što je u lipnju 2018. godine ES donio odluku u predmetu Louboutin, gdje je zauzeo stav kako se u predmetnom slučaju (koji je, op. a., rješavan prema legislativi koja je bila na snazi prije izmjena iz 2015. godine) norma o prepreci za registraciju žiga (kada se kao žig želi registrirati oblik koji značajno utječe na vrijednost proizvoda) ne primjenjuje. Naime, Sud je zauzeo stav da je u ovom slučaju riječ o kolorativno-pozicionom žigu, a ne o oblikov-

\footnotetext{
109 Textilis, par. 42.-47.

110 Usporediti, primjerice, odluke ES-a u predmetima Lego Juris i Textilis. U predmetu Lego Juris ES je ocijenio da se znak koji se želi registrirati kao žig (oblik lego-kocke crvene boje) isključivo sastoji od oblika te da nije od značaja što je podnositelj u prijavi naznačio kako želi registrirati oblikovni žig u crvenoj boji (tj. oblikovno-kolorativni žig). U predmetu Textilis, ES je zauzeto stav kako se ne može smatrati da se figurativni žig koji prikazuje dvodimenzionalni, dekorativni, uzorak koji se primjenjuje na tkaninama, papiru ili sličnim proizvodima, isključivo sastoji od oblika proizvoda.

111 Kada su usvojene Direktiva (EU) 2015/2436 i Uredba (EU) 2015/2424, koja je naknadno kodificirana kao Uredba (EU) 2017/1001

112 Vidjeti, primjerice: Maniatis, S., Whither European trademark law? Arsenal and Davidoff: the creative disorder stage, Marquette Intellectual Property Law Review, god. 7, br. 1, 2003., str. 114.

113 Vidjeti, primjerice, Brancusi, L. Trade Marks' Functionality in EU Law: Expected new Trends after the Louboutin case, European Intellectual Property Review, god. 41, br. 2, 2019., str. 99.

114 Ibidem, str. 99.-101.
} 
nom žigu. ${ }^{115}$ Stoga, (prema stavu ES-a) nema prepreke za registraciju žiga. Međutim, ako bi se nova legislativa mogla primijeniti retroaktivno, registrirani kolorativno-pozicioni Louboutinov žig EU-a ponovno bi se mogao dovesti u pitanje. Ovu mogućnost ipak otklanja ES, u predmetu Textilis, gdje izričito navodi kako se nova legislativna rješenja ne mogu primjenjivati retroaktivno. ${ }^{116}$

Ipak, pojedini pravni teoretičari ističu kako nakon presude Textilis ne treba donositi ishitrene zaključke prema kojima žigove registrirane prije stupanja na snagu nove legislative nije moguće poništiti, unatoč činjenici što je riječ o znakovima koji se isključivo sastoje od karakteristike proizvoda koja značajno determinira vrijednost proizvoda. ${ }^{117} \mathrm{Naime}$, prema tumačenjima ES-a (što smo prikazali u prethodnom poglavlju) pojam "oblik proizvoda" treba tumačiti u veoma širokom kontekstu - na način koji obuhvaća i ostale vanjske karakteristike proizvoda. ${ }^{118} \mathrm{Iz}$ ovoga proizlazi da se i žigovi koji su na području EU-a registrirani prema pravilima koja su bila na snazi prije posljednje revizije žigovnog prava EU-a iz 2015. godine, ipak mogu poništavati pozivanjem na neku od dodatnih apsolutnih prepreka za registraciju žiga. ${ }^{119}$

Stoga se priklanjamo stavu da je posljednjim izmjenama žigovnog prava EU-a europski zakonodavac samo izričito propisao (tj. u Direktivu i Uredbu inkorporirao) pravilo koje je ES već uspostavio u svojoj praksi. Smatramo kako bi bilo svrsishodno da se ovo izričito navelo u preambuli Direktive 2015/2436. Kako to nije učinjeno, Europski sud mogao bi to istaknuti u nekom od narednih predmeta gdje će imati priliku protumačiti neku od dodatnih apsolutnih prepreka za registraciju oblika (ili ostalih karakteristika) proizvoda kao žiga - kako bi se uklonila pravna nesigurnost koja je glede ovog pitanja trenutačno prisutna.

\subsubsection{ZNAČAJAN UTJECAJ NA VRIJEDNOST PROIZVODA}

Činjenica da je oblik oku ugodan (privlačan) nije dovoljna da mu se zbog toga uskrati mogućnost zaštite u okviru žigovnog prava. ${ }^{120} \mathrm{U}$ suprotnom gotovo bi nemoguće bilo osmisliti oblik koji bi bilo moguće registrirati kao žig - imajući u vidu da se danas na tržištu gotovo i ne nude uporabni proizvodi u čiji finalni vanjski izgled (uključujući oblik) nije uložen kreativni doprinos, ali i znatna financijska sredstva.

U načelu, smatra se da oblik daje značajnu vrijednost proizvodu (i tada se ne može registrirati kao žig) ako može, u velikoj mjeri, utjecati na ponašanje potrošača glede kupnje proizvoda utjelovljenih u navedenom obliku. ${ }^{121}$ Dakle, pojam vrijednost odnosi se na vjerojatnost da će

\footnotetext{
115 Louboutin, par. 28.

116 Textilis, par. 48.

117 Više u: Rosati, op. cit. u bilj. 10, str. 17.-22.

118 ES, Louboutin, par. 21: “U kontekstu prava žiga, pojam 'oblik' valja općenito shvatiti, kao što je to istaknula Europska komisija, na način da označava sve linije i obrise koji prostorno ograničavaju proizvod."

119 Tako i: Rosati, op. cit. u bilj. 10, str. 22.

120 Tako i: OHIM, Third Board of Appeal, Case R 395/1999-3, od 3. svibnja 2000. godine, par. 33. Ovo je ES potvrdio u predmetu Gömböc, gdje je u par. 58. i 59. istaknuo kako okolnost da se znak koji se želi registrirati kao žig isključivo sastoji od oblika proizvoda koji ima umjetničku ili ukrasnu vrijednost, ne podrazumijeva da se registracija žiga automatski mora odbiti na temelju prepreke za registraciju koja je predmet analize u ovome radu.

121 Tako i: OHIM, Fifth Board of Appeal, Case R 942/2012-5, od 16. siječnja 2013. godine, par. 11.
} 
potrošači određen proizvod izabrati između drugih proizvoda iste vrste, prvenstveno zbog njegova oblika. U praksi, često nije jednostavno ocijeniti kupuju li potrošači određen proizvod prvenstveno zbog njegova oblika ili oblik ima tek sekundarni utjecaj na ponašanje kupaca. U predmetu koji se vodio u Nizozemskoj, sudovi su odlučivali o oblikovnom žigu grickalice. ${ }^{122}$ Osoba koja je povrijedila registrirani oblikovni žig i koju je nositelj oblikovnog žiga tužio zbog povrede, u sudskom je postupku pokušala poništiti registrirani oblikovni žig za grickalice pozivajući se na to da je ovdje riječ o obliku koji grickalici daje značajnu vrijednost. Zanimljiva je odluka Žalbenog suda koji smatra da se bitna vrijednost grickalice očituje u njezinu okusu i hrskavosti, a ne u njezinu obliku - bez obzira na to što ostale grickalice imaju sličan okus i hrskavost. Pred Vrhovnim sudom tuženi je naveo kako odluku Žalbenog suda smatra kontradiktornom - jer, ako ostale grickalice imaju sličan okus i intenzitet hrskavosti - tada je za kupce od ključnog značenja upravo oblik proizvoda. Ipak, Vrhovni je sud potvrdio odluku Žalbenog suda, uz obrazloženje kako komercijalna vrijednost koju proizvodu daje ugled njime označenog žiga, ne predstavlja dio esencijalne (temeljne) vrijednosti proizvoda. ${ }^{123}$

Na razliku između vrijednosti koju proizvodu daje oblik per se i vrijednosti koju proizvodu daje ugled proizvođača upozorava i EUIPO (prije OHIM), koji ističe da se dodatna prepreka za registraciju žiga ne primjenjuje kada potrošače na kupnju proizvoda motivira ugled (reputacija) vlasnika žiga ili ugled njegovih ostalih žigova. ${ }^{124} \mathrm{U}$ suprotnom bi se prepreka za registraciju žiga (prema kojoj kao žig nije moguće registrirati oblik koji značajno utječe na vrijednost proizvoda) primjenjivala vrlo ekstenzivno. Štoviše, primjenjivala bi se nepravilno (s obzirom na svrhu koja se navedenom odredbom želi ostvariti).

Bitno je naglasiti da se percepcija javnosti prema određenom obilježju proizvoda (npr. obliku) s vremenom može promijeniti te postati manje poželjna ili čak nepoželjna. U tom slučaju više ne bi bili ispunjeni uvjeti za primjenu ovdje analizirane prepreke za registraciju žiga te bi se znak koji se sastoji od takve (sada manje privlačne/neprivlačne) karakteristike mogao registrirati kao žig - pod pretpostavkom da udovoljava ostalim pretpostavkama za registraciju žiga. Dakle, iako ovdje analizirana prepreka jest apsolutna i "nepremostiva” (jer će biti relevantna unatoč činjenici što je sporni oblik postao distinktivan uporabom) to ne znači da ova prepreka može djelovati unedogled - budući da mogućnost njezine primjene uvelike ovisi o percepciji potrošača koja je promjenjiva.

ES je u predmetu Hauck ${ }^{125}$ istaknuo kako sintagmu "značajna vrijednost" treba široko tumačiti. Naglasio je kako se navedena sintagma ne odnosi samo na oblike proizvoda koji imaju isključivo umjetničku ili ukrasnu vrijednost, već i na oblike koji uz estetsku vrijednost imaju i funkcionalnu vrijednost. Naime, ES smatra kako se analizirana prepreka za registraciju žiga

122 Riječ je o predmetu Bahlsen v Smith (poznatijem kao Wokkels Case) u povodu kojeg je nizozemski Vrhovni sud (Hoge Raad) donio odluku 11. studenoga 1983. godine. O predmetu Wokkels, vidjeti više u: Kur, op. cit. u bilj. 17, str. 10.-11. te Gielen, op. cit. u bilj. 17, str. 166.

123 Gielen, op. cit. u bilj. 17, str. 166.

124 Vidjeti: OHIM, Fifth Board of Appeal, Case R 942/2012-5, od 16. siječnja 2013. godine, par. 11., 12. i 19. ES je ovo potvrdio u predmetu Gömböc, kada je istaknuo kako se (u ovom radu analizirana prepreka za registraciju žiga) primjenjuje ako iz objektivnih i vjerodostojnih elemenata proizlazi da je izbor potrošačâ u značajnoj mjeri određen jednom ili više značajki proizvoda (par. 59), pri čemu ni na koji način nije isključeno da bitna vrijednost te vrste predmeta može proizlaziti i zbog razloga koji ne proizlaze iz vanjskog izgleda proizvoda, poput: povijesti njihova stvaranja, načina izrade, materijala od kojih su izrađeni, identiteta njihova dizajnera i sl. (par. 60.). 
može primijeniti i na znak koji se isključivo sastoji od oblika proizvoda s više značajki koje mu mogu dati različite bitne vrijednosti. ${ }^{126}$ ES smatra kako je ovakvo tumačenje nužno jer se u suprotnom (na oblike koji uz estetsku vrijednost imaju i funkcionalnu vrijednost) ne bi mogla primijeniti odredba prema kojoj se kao žig ne može registrirati oblik koji značajno determinira vrijednost proizvoda - što bi moglo narušiti tržišnu utakmicu. ${ }^{127}$ Ovakvo obrazloženje čini nam se spornim - budući da bi se u navedenoj situaciji moglo primijeniti pravilo prema kojem se kao žig ne može registrirati oblik koji ima tehničku funkciju - što znači da tržišna utakmica ne bi bila narušena. Čini se da nakon odluke ES-a u predmetu Hauck više nisu jasne granice između tri dodatne prepreke za registraciju oblika proizvoda (i ostalih karakteristika proizvoda) kao žiga - što svakako ne pridonosi pravnoj predvidljivosti i sigurnosti.

Dodatno, odluka ES-a u predmetu Hauck značajna je i jer je u njoj ES istaknuo da percepcija znaka od strane ciljane javnosti ne bi trebala biti odlučujući čimbenik pri odlučivanju jesu li ispunjeni uvjeti za primjenu prepreke prema kojoj kao žig nije moguće registrirati obilježje koje značajno determinira vrijednost proizvoda. Međutim, takva percepcija javnosti može biti relevantan kriterij za ocjenu nadležnog tijela glede pitanja koje su značajke bitne, a koje ne. ${ }^{128}$ Dakle, prema stavu ES-a, percepcija oblika proizvoda od strane ciljane javnosti samo je jedan od kriterija pri ocjenjivanju treba li, u konkretnom slučaju, primijeniti ovdje analiziranu prepreku za registraciju žiga ili ne. ${ }^{129} \mathrm{U}$ tom smislu, prema ES-u, mogli bi se uzeti u obzir i drugi kriteriji za ocjenu utječe li oblik značajno na vrijednost proizvoda ili ne, primjerice: narav predmetne kategorije proizvoda, umjetnička vrijednost oblika o kojem je riječ, posebnost tog oblika u odnosu na druge oblike općenito prisutne na predmetnom tržištu, značajna razlika u cijeni u odnosu na slične proizvode ili razvoj promidžbene strategije koja ponajprije ističe estetske značajke predmetnog proizvoda. ${ }^{130}$ Smatramo kako su neki od ovdje navedenih kriterija prilično subjektivne naravi (npr. umjetnička vrijednost oblika) te nije jasno na koji bi ih način nadležno tijelo, u praksi, trebalo ocjenjivati - posebice kada je riječ o registarskim tijelima koja (glede pitanja jesu li ispunjeni uvjeti za primjenu ovdje analizirane dodatne prepreke za registraciju žiga) trebaju donijeti objektivnu i apstraktnu odluku. ${ }^{131}$

\section{MOŽE LI SE FUNKCIJA ODREDBE IZ ČLANKA 4. (1) (E) (III) DIREKTIVE (EU) 2015/2436 I ČLANKA 7. (1) (E) (III) UREDBE (EU) 2017/1001 OSTVARITI POZIVANJEM NA NERAZLIKOVNOST}

Prema Studiji Max Planck Instituta iz 2011. godine, oblik proizvoda koji nije razlikovan, ne bi se mogao registrirati kao žig. Međutim, ako bi oblik proizvoda uporabom postao razlikovan

\footnotetext{
126 Hauck, par. 36 .

127 Hauck, par. 32.

128 Hauck, par. 34 .

129 Hauck, par. 44.

130 Hauck, par. 35.

131 Više o kriterijima koje bi nadležna tijela (prema Odluci ES-a iz predmeta Hauck) trebala uzimati u obzir pri ocjeni značajne vrijednosti, vidjeti u: Kur, op. cit. u bilj. 11, str. 23.-24.
} 
- tada ne bi trebalo biti prepreke za registraciju. ${ }^{132}$ Ovaj prijedlog podupiru i mnogi pravni teoretičari. ${ }^{133}$ Oni polaze od teze kako je u potonjoj situaciji (kada je oblik na tržištu postao razlikovni znak) vrijednost proizvoda značajno determinirana ugledom proizvođača, a na oblikom proizvoda. Odnosno, iako su potrošači izvorno proizvod kupovali zbog izgleda, ispostavilo se da su proizvodom zadovoljni i da su ga nastavili kupovati zbog njegove kvalitete koju su počeli dovoditi u vezu s proizvođačem. Dakle, nakon određenog vremena potrošači su (navodno) počeli kupovati određeni proizvod (čijeg proizvođača prepoznaju prema izgledu proizvoda) prvenstveno zbog kvalitete (i ugleda proizvođača), a ne zbog izgleda. ${ }^{134}$ Smatramo da ovo obrazloženje nije primjenjivo u svim situacijama te je moguće da potrošači proizvod kupuju prvenstveno zbog njegova vanjskog izgleda i nakon što su vanjski izgled proizvoda počeli dovoditi u vezu s određenim proizvođačem. Takvi bi potrošači bili spremni kupiti istovjetan proizvod od drugog proizvođača, posebice ako bi se na tržištu nudio po nižoj cijeni. Nadalje, Max Planck (i oni koji podržavaju njegov stav) smatraju da se ratio odredbe o značajnoj vrijednosti oblika proizvoda kao prepreke za registraciju žiga ne očituje u osiguranju uvjeta za pravičnu tržišnu utakmicu. ${ }^{135}$ Oni smatraju da se obrazloženje ES-a iz predmeta Philips ${ }^{136}$ (prema kojem se svrha članka 3 (1) (e) Direktive 89/104/EEZ očituje u sprječavanju narušavanja pravične tržišne utakmice ${ }^{137}$ ) zapravo ne proteže na pravilo o značajnoj vrijednosti oblika proizvoda kao prepreci za registraciju žiga. Naime, prema navedenim autorima, ne postoji opravdan razlog zbog kojeg bi pravni sustav imao interesa štititi pretenzije konkurenata na vanjski izgled proizvoda koji je toliko prepoznatljiv da ga potrošači dovode u vezu s njegovim proizvođačem, unatoč činjenici da je riječ o obliku koji proizvodu daje značajnu vrijednost. ${ }^{138}$ Štoviše, ovi autori smatraju da bi se, u suprotnom (tj. kada stjecanje žigova nad takvim oblicima proizvoda ne bi bilo dopušteno) poduprli oni tržišni takmaci koji, umjesto da razvijaju svoje proizvode specifičnog izgleda, kopiraju izgled najuspješnijih proizvoda svojih konkurenata - čime im potpuno neopravdano oduzimaju udio u dobiti, a potrošače dovode u zabludu. ${ }^{139}$

Unatoč prijedlozima Max Planck Instituta iz 2011. godine, koji su zadobili prilično široku potporu među pravnim teoretičarima, europski zakonodavac (pri reviziji žigovnog prava koja je uslijedila) nije u pravne akte iz područja žigovnog prava inkorporirao odredbu prema kojoj se, postane li oblik proizvoda razlikovan, odredba o značajnoj vrijednosti oblika proizvoda više ne primjenjuje kao prepreka za registraciju žiga. Štoviše, europski zakonodavac izričito je predvidio da se navedena prepreka primjenjuje i na ostale karakteristike koje značajno determiniraju vrijednost proizvoda, ako ih se želi registrirati kao žig - čime je izričito potvrdio da je riječ o prepreci koja se, ratione materiae, ima primjenjivati u najširem kontekstu. ${ }^{140}$

132 Max Planck, op. cit. u bilj. 25, str. 74, par. 2.34.

133 Primjerice, Gielen, op. cit. u bilj. 17, str. 169.

134 Slično navodi: Kur, op. cit. u bilj. 17, str. 18.

135 Vidjeti: Gielen, op. cit. u bilj. 17, str. 167.

136 Oznaka Odluke ES-a u predmetu Philips navedena je supra - u bilj. 14.

137 Philips, par. 78.

138 Gielen, op. cit. u bilj. 17., str. 168. i 169.

139 Ibidem, str. 169.: “(...) from a competition point of view there is no real and compelling need for competitors to be able to use a design like the Burberry check or the Elwood jeans design after the copyright or design rights therein have expired."

140 Iako neki autori smatraju da je navedenom reformom prošireno polje primjene dodatnih prepreka za registraciju žigova, smatramo da je cilj zakonodavca bio pojasniti da se navedene prepreke ne primjenjuju samo na oblike (u užem smislu) što je ES već protumačio kroz svoju praksu. O ovome je više govora bilo ranije - supra 3.2.1. i 3.2.2. 
Iako europski zakonodavac nije obrazložio što ga je motiviralo na ovdje opisano postupanje, vjerujemo da je razlog ovakvog postupanja u tome što je procijenio (prema našem sudu, ispravno) da je ultimativni cilj ovdje analizirane odredbe zaštita interesa javnosti. Naime, interes javnosti svakako je narušen ako se nekome (u vremenski neograničenom trajanju) dodijele isključiva subjektivna prava (što de facto predstavlja monopol) nad neodvojivim dijelom proizvoda, nad kojim pripadnici javnosti imaju interes zbog bilo kojeg razloga - primjerice, jer je riječ o obliku koji ima određenu funkciju ili je oblik jednostavno privlačan - bilo zbog pukog estetskog razloga ili zbog razloga što prenosi poruku koju potrošači “žele čuti”. Zamislimo situaciju gdje proizvođač parfema dugi niz godina na tržištu nudi parfeme u bočicama u obliku dijamanta po kojima je postao prepoznatljiv među potrošačima. Kada ne bi bilo u ovom radu analizirane prepreke za registraciju žiga - proizvođač bi oblik bočice parfema mogao registrirati kao oblikovni žig - budući da znak nije opisan, distinktivan je, ne proizlazi izravno iz prirode proizvoda te nema tehničku funkciju. S druge strane, oblik dijamanta je oblik koji postoji u prirodi i uz koji se vezuju brojne konotacije - kao što su luksuz, ekskluzivitet, dragocjenost, prestiž i sl. Mnogi će potrošači (vrlo vjerojatno) među brojnim drugim parfemima, odabrati upravo ovaj parfem, pri čemu će biti vođeni suptilnom porukom sadržanom u njegovu pakiranju. Postavlja se pitanje, treba li nekome zaista dopustiti monopol nad oblikom kao što je dijamant - koji, dakle, postoji u prirodi i koji "nosi" određenu poruku. Isto vrijedi i za ostale oblike/vanjske karakteristike proizvoda koje mogu biti privlačne kupcima zbog razloga koji je svojstven samom tom obliku ili karakteristici, a nije posljedica promidžbenih aktivnosti ili ugleda proizvođača. ${ }^{141}$ Prema našem stavu, takvi bi oblici (i ostale karakteristike proizvoda) trebali ostati izvan dosega zaštite u okviru žigovnog prava. U iznimnim situacijama, kada takvi oblici postanu razlikovni (zahvaljujući dugotrajnoj uporabi i/ili promidžbenim aktivnostima) te udovoljavaju ostalim apsolutnim preprekama za registraciju žiga, čini se da ovdje analizirano pravilo predstavlja "posljednju branu" koja sprječava neopravdanu ekstenziju žigovnog prava i na objekte koji izvorišno ovakvim vidom zaštite nisu bili obuhvaćeni, niti se njihovo naknadno podvrgavanje mogućnosti zaštite u okviru žigovnog prava može opravdati pozivanjem na svrhu koja se žigovnim pravom nastoji ostvariti.

Možemo zaključiti kako (u praksi) velik broj oblikovnih žigova (koji se isključivo sastoje od oblika proizvoda) nisu inherentno razlikovni. Takvi se oblici, stoga, ne bi mogli registrirati kao žig niti kada prepreka za registraciju koja je predmet analize u ovome radu ne bi postojala. Međutim, neki inherentno nerazlikovni oblici postat će razlikovni uporabom. Kada ne bi postojala ovdje analizirana nepremostiva prepreka za registraciju žiga, takvi bi se oblici mogli registrirati kao žig. Smatramo da u nekim slučajevima - tj. u slučajevima kada oblik ima funkciju (bilo da je riječ o tehničkoj funkciji ili o funkciji koja se očituje u privlačenju kupaca zbog bilo kojeg drugog razloga osim puke tehničke funkcije) nad takvim oblikom permanentni monopoli ne bi smjeli biti dopušteni. Dakle, opća prepreka, prema kojoj se nerazlikovni znakovi ne mogu registrirati kao žig, ovakve monopole ne sprječava - iz čega izvodimo zaključak da se tom odredbom ne može ostvariti svrha koja se ostvaruje ovdje analiziranom preprekom za registraciju žigova (kao što neki autori tvrde). Stoga, smatramo da u ovom radu analizirana dodatna prepreka za registraciju žigova treba zadržati svoje mjesto u europskom sustavu žigovnog prava, ali ju treba precizirati (ili barem ispravno tumačiti) kako bi prestala biti izvorom pravne nesigurnosti.

141 Primjera radi, smatramo kako ne bi bilo opravdano nekome omogućiti stjecanje prava žiga nad rasvjetnim tijelom u obliku vodovodne cijevi - ni pod pretpostavkom da je na određenom tržištu takav oblik postao distinktivan. Riječ je o obliku koji ne proizlazi iz prirode proizvoda, niti je nužan za ostvarivanje tehničkog rezultata, ali zasigurno privlači brojne kupce. 


\section{SUDSKA PRAKSA}

\subsection{NJEMAČKA}

Registarska tijela u zemljama članicama EU-a (isto vrijedi i za OHIM - danas EUIPO - kada je riječ o žigovima EU-a) prilično rijetko odbijaju registrirati oblikovne žigove pozivajući se na neku od dodatnih apsolutnih prepreka za registraciju oblikovnih žigova. S druge strane, veoma često odbijaju registrirati oblikovne žigove pozivajući se na nerazlikovnost oblika. ${ }^{142}$ Stječe se dojam kako se registarska tijela prema dodatnim apsolutnim preprekama za registraciju žigova odnose kao prema "osinjem gnijezdu" koje je bolje ne dirati, kad god je to moguće ${ }^{143}-i z$ čega se može zaključiti da su svjesni problema koje za sobom povlači primjena dotičnih pravila. ${ }^{144}$ Osobito se rijetko registarska tijela pozivaju na pravilo o značajnoj vrijednosti oblika proizvoda kao prepreci za registraciju žiga. ${ }^{145}$ Nešto se učestalije na ovo pravilo (kao i na preostale dvije dodatne prepreke za registraciju oblika proizvoda kao žigova) pozivaju osobe koje su tužene zbog povrede registriranog žiga - koje, dakle, imaju za cilj da se već registrirani žig (koji su navodno povrijedile) utvrdi ništetnim.

U nastavku rada analizirat ćemo dva primjera iz prakse njemačkih sudova. Njemačka sudska praksa čini nam se posebno zanimljivom, budući da je riječ o zemlji članici EU-a koja je, baš kao i RH, svoja nacionalna pravila iz područja žigovnog prava morala uskladiti s odredbama direktiva o harmonizaciji žigovnog prava. Usto, riječ je o državi čiji su nacionalni propisi poslužili kao uzor pri usvajanju mnogih hrvatskih zakona. ${ }^{146}$ Stoga je u RH postalo uobičajeno upravo njemačku sudsku praksu tretirati kao svojevrsni “model” koji može ponuditi rješenje, ako se istovjetni ili slični predmet pojavi pred nadležnim tijelima na području RH. Ovo, svakako, ne znači da bi naša nadležna tijela trebala nužno i nekritički primjenjivati rješenja iz njemačke prakse - posebice ako je riječ o rješenjima koja su izazvala brojne kritike u relevantnoj javnosti.

\subsubsection{SCHMUCKRING}

U predmetu Schmuckring, ${ }^{147}$ predmet spora je vanjski izgled prstena koji se sastoji od dragog kamenja poredanog u obliku cvijeta. Prema Saveznom patentnom sudu ovdje je riječ o obliku

142 Slično i: Kur, op. cit. u bilj. 17, str. 11.-12.

143 Naime, u praksi je veoma često moguće odbiti registraciju žiga (za znak koji prikazuje oblik proizvoda) na temelju nerazlikovnosti, koju je naknadno moguće prevladati uporabom.

144 Primjerice, u predmetu The London Taxi Corporation Ltd ( $\mathrm{t} / \mathrm{a}$ the London Taxy Company) v Frazer-Nash Research Ltd \& Anor, od 1. studenoga 2017. godine, pod par. 76., Žalbeni sud Engleske i Walesa istaknuo je kako i dalje nema jasnih smjernica o tome kako postupiti u praksi kada treba procijeniti utjecaj oblika na vrijednost proizvoda. Da nejasna pravila dovode do različitih odluka u gotovo istovjetnim situacijama, upozorava i Max Planck Institut (op. cit. u bilj. 25, na str. 70.) koji ističe kako se dodatne apsolutne prepreke za registraciju oblikovnih žigova veoma često različito primjenjuju u gotovo istovjetnim situacijama, čak i unutar istih tijela.

145 Od tri dodatne apsolutne prepreke za registraciju žiga kada znak prikazuje oblik proizvoda, najčešće se primjenjuje prepreka prema kojoj se kao žig ne može registrirati oblik proizvoda koji je nužan za ostvarivanje tehničkog rezultata - prema: Kur, op. cit. u bilj. 17, str. 11.

146 Primjerice, pri usvajanju Zakona o trgovačkim društvima 1993. godine, pri usvajanju Zakona o autorskim i srodnim pravima iz 2003. godine i sl.

147 Savezni patentni sud (BPatG), predmet Schmuckring, od 29. rujna 2001. godine. Više o navedenom predmetu, vidjeti u: Kur, A., op. cit. u bilj. 17, str. 12. 
koji daje značajnu vrijednost prstenu. Savezni patentni sud pritom je naglasio da smatra kako bi ovo trebalo biti opće pravilo za sav nakit - odnosno, da oblik uvijek daje značajnu vrijednost nakitu. Iako bi se o utemeljenosti ovog obrazloženja moglo raspravljati, ono je dalo jasne smjernice u vezi s pitanjem kako će sud tretirati eventualne buduće pokušaje monopolizacije vanjskog izgleda različitih komada nakita primjenom oblikovnih žigova. Stoga, ne iznenađuje podatak da nakon ove sudske odluke takvih pokušaja (na području Njemačke) nije bilo. ${ }^{148}$

\subsubsection{FRONTHAUBE}

U drugom slučaju njemačka nadležna tijela odlučivala su o mogućnosti da se kao oblikovni žig registrira vanjski izgled rezervnih dijelova automobila, uključujući i vanjski izgled haube automobila marke BMW. Registarsko tijelo odbilo je zatraženu registraciju, a tu je odluku potvrdio i njemački Savezni patentni sud, pri čemu je u obrazloženju naveo nekoliko razloga. ${ }^{149}$ Prije svega, oblik proizvoda ( $\mathrm{tj}$. automobilske haube) uvjetovan je njegovom tehničkom funkcijom. Nadalje, riječ je o obliku koji proizvodu daje značajnu vrijednost - budući da bi svaki drugi oblik zamjenske haube odvratio kupce od kupnje. ${ }^{150}$ Iz ovoga možemo izvesti zaključak kako Savezni patentni sud smatra (iako to ne navodi izričito) da značajna vrijednost proizvoda može proizlaziti i iz oblika koji nije nužno estetski privlačan (tj. "lijep”), ali značajno utječe na potražnju kupaca zbog bilo kojeg drugog razloga - što je ES kasnije potvrdio u predmetu Hauck. ${ }^{151}$

Ipak, Vrhovni sud Savezne Republike Njemačke (dalje u tekstu: BGH) poništio je odluku Saveznog patentnog suda. ${ }^{152}$ Prije svega, Vrhovni je sud istaknuo kako, unatoč činjenici što zbog tehničke funkcije rezervnih dijelova, njihovi dizajneri imaju ograničenu mogućnost pri kreiranju njihova izgleda - mogućnost izbora (tj. kreiranja drugačijeg izgleda) ipak postoji. Stoga, vanjski izgled proizvoda (zamjenske haube) nije isključivo uvjetovan tehničkom funkcijom proizvoda - što znači da se registracija žiga ne može odbiti pozivanjem na tehničku

148 Loc. cit.

U RH je 2019. godine trgovačko društvo sa sjedištem u Zagrebu, pri DZIV-u registriralo pravo industrijskog dizajna nad privjescima u obliku srca, sidra i sl. (Više o ovom slučaju, vidjeti u: Biberović, M., Slučaj Borboleta: Zaštitila dizajn, narušila si ugled, od 19. srpnja 2019. godine, dostupno na: https://www.netokracija.com/borboleta-zastita-dizajna-tuzbe-159106. Pristupljeno 15. travnja 2020. godine.) Iako je riječ o oblicima koji (vrlo vjerojatno) nisu novi, niti imaju individualni karakter (dakle, prilično je izvjesno da ne zadovoljavaju meritorne uvjete za registraciju prava industrijskog dizajna) registracija je dopuštena zato što prema pozitivnopravnoj regulativi DZIV (u postupku registracije prava industrijskog dizajna) provjerava tek je li podnesena prijava formalno potpuna. Očekujemo da će ova prava industrijskog dizajna biti poništena. Međutim, nije isključeno da će ovaj poduzetnik (ili netko od poduzetnika tko u svom poslovanju primjenjuje sličan modus operandi) navedene oblike privjesaka pokušati registrirati kao oblikovne žigove. Ako je riječ o oblicima privjesaka koji nisu razlikovni (npr. sidro u uobičajenom obliku), DZIV bi se pri odbijanju registracije mogao pozvati na nerazlikovnost. Međutim, ako je riječ o obliku privjeska koji je specifičan te ga se ne može smatarti nerazlikovnim (npr. sidro u znatno stiliziranom obliku) odluka njemačkog Saveznog patentnog suda u predmetu Schmuckring, DZIV-u bi mogla poslužiti kao uzor. Ipak, smatramo da ne treba a priori izvoditi zaključak kako oblik nakita uvijek značajno utječe na njegovu vrijednost te ga se ne bi trebalo moći registrirati kao oblikovni žig. Kur, (op. cit. u bilj. 17, na str. 12.) navodi primjer nakita (naušnica) koje u 3D obliku prikazuju slova "CD" što ukazuje na proizvođača "Christiana Diora", a vrijednost proizvoda proizlazi iz ugleda proizvođača. Stoga, Kur naglašava da bi u takvim situacijama trebalo omogućiti registraciju, unatoč odluci njemačkog Saveznog patentnog suda u predmetu Schmuckring. 149 Savezni patentni sud (BPatG), predmet Kraftfahrzeugteile, iz 2005. godine. Više o navedenom predmetu, vidjeti u: ibidem, str.
12.

150 Loc. cit.

151 Hauck, par. 32.

152 Vrhovni sud Savezne Republike Njemačke (BGH), predmet Fronthaube, iz 2008. godine. Više o ovome predmetu, vidjeti u: Kur, op. cit. u bilj. 17, str. 12.-13. 
funkciju. ${ }^{153}$ Nadalje, prema stavu Vrhovnog suda, pojam “značajna vrijednost” iz članka 3 (1) (e) (iii) Direktive 2008/95/EZ (koji je bio implementiran u njemačko žigovno pravo) odnosi se samo na estetski izgled proizvoda te ne obuhvaća ostale razloge koji utječu na prodaju. ${ }^{154}$ Teško je razumjeti iz čega Vrhovni sud izvodi ovakvu argumentaciju na temelju koje značajno sužava polje primjene ovdje analizirane apsolutne prepreke za registraciju žiga. Budući da članak Direktive na kojeg se BGH poziva ne sadrži niti sintagmu "estetska funkcija”, niti bilo koju drugu sintagmu ili termin koji bi imao slično značenje, ne možemo shvatiti argumentaciju na temelju koje se polje primjene navedene odredbe svodi tek na oblike koji su estetski privlačni (u najužem smislu). Čak i ako je bio u nedoumici glede načina na koji treba tumačiti navodno spornu odredbu Direktive, BGH je trebao zastati s postupkom i zatražiti od ES-a da protumači odnosi li se ovdje sporna prepreka za registraciju žiga na bilo koju situaciju gdje oblik (zbog bilo kojeg razloga) daje značajnu vrijednost proizvodu ili samo na situaciju gdje značajna vrijednost proizvoda proizlazi iz estetske funkcije njegova oblika, tj. iz privlačnog izgleda proizvoda. ${ }^{155}$ Stoga se ne možemo oteti dojmu kako je BGH, pri odlučivanju u ovom predmetu, bio vođen gospodarskim interesima koji imaju za cilj osnažiti tržište originalnim automobilskim dijelovima, na uštrb tržišta zamjenskim automobilskim dijelovima.

\subsection{SUDOVI EU-A}

Temeljita analiza odredbe prema kojoj kao žig nije moguće registrirati obilježje koje značajno determinira vrijednost proizvoda, uz analizu odluka Sudova EU-a u predmetima Benetton v. G-Star te Bang \& Olufsen (koje ćemo prikazati u nastavku rada), zahtijeva i analizu odluka u predmetima Hauck, Louboutin, Textilis i Gömböc. Budući da smo se na navedene odluke (u manjoj ili većoj mjeri) već osvrnuli u radu, smatramo da nema potrebe i u ovom dijelu rada ponavljati stajališta koja je Europski sud iznio u navedenim odlukama.

\subsubsection{BENETTON v. G-STAR}

U predmetu Benetton v. G-Star ${ }^{156}$ riječ je o sporu između proizvođača traperica. Proizvođač traperica (G-Star) imao je, na području Beneluxa, registriran oblikovni žig za traperice koje je na tržištu nudio pod nazivom Elwood. Zbog povrede ovog žiga, G-Star je podnio tužbu protiv Benettona, koji je na tržištu nudio traperice sličnog izgleda. Zbog toga je Benetton zatražio da se sporni žig poništi jer predstavlja oblik (vanjski izgled) traperica koji proizvodu daje značajnu vrijednost. Prvostupanjski sud odbio je oba zahtjeva - smatrajući kako je registrirani žig valjan, ali u konkretnom slučaju nije povrijeđen. ${ }^{157}$ Žalbeni sud (Gerechtshof de Amsterdam) potvrdio je kako je sporni žig valjan. Međutim, ocijenio je da ga je Benetton povrijedio. Žalbeni je sud u obrazloženju svoje odluke istaknuo kako je G-Star poduzeo brojne marketinške aktiv-

153 Ibidem, str. 12.

154 Fronthaube, par. 71.-72.

155 Tako i: Kur, op. cit. u bilj. 17, str. 13.

156 Benetton Group SpA v G-Star International BV (C-371/06) od 20. rujna 2007. godine.

157 Prema: Kur, op. cit. u bilj. 17, str. 14. 
nosti kako bi potrošači specifičan izgled traperica počeli dovoditi u vezu s njime. Na taj je način žig postao razlikovan, a vrijednost Elwood traperica (u trenutku registracije žiga) proizlazila je (prema stavu žalbenog suda) iz ugleda proizvođača - što nije prepreka za registraciju žiga. ${ }^{158}$ Nezadovoljan ovom odlukom, Benetton se obratio kasacijskom sudu, tj. nizozemskom Vrhovnom sudu (Hoge Raad) koji je ocijenio kako odluka u ovom sporu ovisi o tumačenju europskog žigovnog prava te je zastao s postupkom i od ES-a zatražio odgovor na pitanje: primjenjuje li se odredba Direktive o harmonizaciji žigovnog prava (kojom je predviđeno da se kao žig ne mogu registrirati oblici proizvoda koji značajno utječu na vrijednost proizvoda) i u situaciji kada je riječ o znaku koji se izvorno sastojao od oblika koji je privlačan te proizvodu daje vrijednost, ali je prije podnošenja prijave za registraciju taj znak, radi promidžbenih aktivnosti, postao razlikovni znak? ${ }^{159}$ Sud je zaključio kako činjenica da je znak (koji u ovom slučaju predstavlja oblik proizvoda) postao razlikovan, ne predstavlja razlog zbog kojeg se ne bi trebala primijeniti neka od dodatnih prepreka za registraciju oblikovnih žigova - uključujući i prepreku prema kojoj se kao žig ne može registrirati oblik proizvoda koji značajno utječe na vrijednost proizvoda. ${ }^{160}$

Ostaje žal što se ES pri donošenju odluke u ovom predmetu striktno držao odgovora na postavljeno pitanje ${ }^{161} \mathrm{i}$ što se, u obrazloženju odluke, tek pozvao na odluku u predmetu Phillips te na puku dikciju Direktive o harmonizaciji žigovnog prava. Smatramo da je Sud trebao pojasniti što učiniti u situaciji kada oblik (izgled) proizvoda kojeg se želi registrirati kao žig jest privlačan, ali je postao i razlikovan te kupci proizvod prvenstveno kupuju zbog ugleda proizvođača. U ovoj situaciji, dakle, oblik ne samo da je postao razlikovan, nego je primarni razlog kupnje u tom obliku utjelovljenih proizvoda prestala biti privlačnost njihova oblika. Takvih je slučajeva u praksi mnogo, a nadležna tijela nemaju jasnu uputu kako postupiti u opisanoj situaciji. Smatramo da u takvoj situaciji ne bi trebalo zauzeti stav da je vrijednost proizvoda značajno determinirana pukim izgledom proizvoda (koji jest privlačan), već ugledom proizvođača - jer je to razlog zbog kojeg većina potrošača kupuje dotične proizvode. Prema smjernicama EUIPO-a, kada proizvod ima vrijednost zbog ugleda njegova proizvođača - tada se apsolutna prepreka za registraciju žigova koja je predmet analize u ovom radu ne primjenjuje. ${ }^{162}$ Međutim, niti EUIPO, niti ES, još nisu dali jasne smjernice kako postupiti u situaciji kada na vrijednost proizvoda utječu i izgled (oblik) proizvoda i ugled proizvođača - odnosno, u kojoj mjeri ugled proizvođača mora prevladati izgled proizvoda da bi mogli zaključiti kako je upravo ugled proizvođača čimbenik koji u značajnoj mjeri determinira vrijednost proizvoda (a ne izgled proizvoda) - što znači da se dodatna prepreka za registraciju žiga ne bi trebala primijeniti.

158 Loc. cit.

159 Ovako je ES parafrazirao pitanje koja mu je u povodu zahtjeva za prethodno odlučivanje postavio nizozemski Vrhovni sud prema ibidem, str. 15 .

160 Pritom se ES (u Benetton v G-Star, par. 26) pozvao na svoju odluku iz predmeta Philips, ali i na dikciju Direktive 89/104/EEC iz članka 3(3) - vidjeti: Benetton v G-Star, par. 24.-25.

161 Kur, op. cit. u bilj. 17, str. 15., pod bilj. 55, navodi cijeli niz odluka u kojima se ES nije striktno držao postavljenih pitanja, već je odgovor "proširio" kako bi razjasnio potencijalne nejasnoće koje su blisko vezane s postavljenim pitanjem, iako postavljenim pitanjem nisu izričito obuhvaćene.

162 EUIPO, op. cit. u bilj. 54, Part B, Sec (4), Chapter 6 (4): “The concept of 'value' should not be interpreted as meaning 'reputation', since application of this absolute ground for refusal is justified exclusively by the effect on the value added to the goods by the shape or other characteristic and not by other factors, such as the reputation of the word mark that is also used to identify the goods in question." 


\subsubsection{Bang \& Olufsen}

Danski proizvođač high-tech i audio opreme Bang \& Olufsen od 1992. godine pod nazivom BeoLab 800 na tržištu nudi zvučnike specifičnog oblika (oblik olovke). Tržište Bang \& Olufsena nije veliko (u apsolutnim brojkama), ali unutar tržišnog segmenta na kojem nude svoje proizvode, uživaju izniman ugled te neki njihovi proizvodi (npr. zvučnici BeoLab 800) imaju status ikone. ${ }^{163}$ Godine 2003. Bang \& Olufsen podnio je prijavu OHIM-u s ciljem registracije oblikovnog žiga EZ-a za zvučnike. OHIM je registraciju odbio uz obrazloženje da je riječ o obliku koji nije razlikovan, a ovu je odluku potvrdilo i Žalbeno vijeće OHIM-a. ${ }^{164}$ Međutim, Opći je sud poništio ovu odluku, uz obrazloženje da je riječ o obliku koji je zaista specifičan, značajno se razlikuje od oblika uobičajenih u relevantnom tržišnom sektoru te ga, stoga, treba smatrati razlikovnim i omogućiti mu registraciju. ${ }^{165}$

Međutim, OHIM je ponovno odbio registrirati oblikovni žig za opisane zvučnike, ovoga puta pozivajući se na odredbu o značajnoj vrijednosti oblika proizvoda kao prepreci za registraciju žiga. ${ }^{166}$ Odluku OHIM-a potvrdio je i Opći sud. ${ }^{167}$ Prema stavu OHIM-a i Općeg suda, ovdje oblik daje značajnu vrijednost proizvodu jer predstavlja upečatljiv, lako pamtljiv dizajn, a upravo je dizajn čimbenik koji će biti iznimno značajan pri odlučivanju potrošača o kupnji proizvoda - čak i ako potrošači uzmu u obzir ostale karakteristike proizvoda. ${ }^{168}$

Smatramo kako je zaista sporno koliko je prosječnom potrošaču, pri kupnji zvučnika, značajan njegov vanjski izgled. Ako je i značajan, vjerujemo da kod većine kupaca vanjski izgled nije presudan čimbenik pri kupnji zvučnika.

Ovaj predmet najslikovitije dočarava koliko je odredba o značajnoj vrijednosti oblika proizvoda (kao prepreka za registraciju žiga) opasna kada je o privlačnim dizajnima riječ, primjenjuje li se tu odredbu protivno svrsi radi koje je implementirana u sustav žigovnog prava. Smatramo kako zaista ne postoji opravdan razlog zašto najprivlačniji dizajn ne bi imao pravo na zaštitu, dok bi manje privlačan dizajn (koji ipak dovoljno odudara od dizajna uobičajenih u dotičnom tržišnom sektoru da ga se može smatrati razlikovnim; ili koji je razlikovnost stekao uporabom), imao pravo na zaštitu u okviru žigovnog prava.

Čini se kako bi se pri tumačenju ovdje analizirane prepreke trebalo usmjeriti (tj. vratiti) na ratio radi kojeg je ovo pravilo (u sličnom, ali doktrinarnom obliku) uspostavljeno na području SAD-a, a kojeg je (pri tumačenju odredbe danas sadržane u članku 4 (1) (e) (iii) Direktive (EU) 2015/2436) potvrdio i ES, a to je: uspostavljanje uvjeta za pravičnu tržišnu konkurenciju. Ovaj ratio ostvaruje se u praksi ako se ne dopuštaju permanentni monopoli nad segmentima proizvoda koji su nužni da bi zdrava konkurencija, na određenom tržištu, zaista mogla postojati. Postavimo si konkretno pitanje: mogu li konkurenti nuditi visokokvalitetne zvučnike, zanimljivog dizajna, ako im se onemogući nuditi zvučnike u obliku olovke - jer na takvim oblicima

\footnotetext{
163 Prema: Kur, A. op. cit. u bilj. 17, str. 2.

164 Loc. cit.

165 Opći sud, Bang \& Olufsen v OHIM (T-460/05) od 10. listopada 2007. godine.

166 OHIM - case R 497/2005-1, od 22. rujna 2005. godine.

167 Bang \& Olufsen v OHIM (Shape of a loudspeaker) II (T-508/08), od 6. listopada 2011. godine.

168 Bang \& Olufsen v OHIM (Shape of a loudspeaker) II, par. 74.-78.
} 
zvučnika isključivo pravo žiga ima jedan proizvođač? Odgovor je - mogu. Postavimo si zatim iduće pitanje: mogu li konkurenti na tržištu nuditi traperice zanimljivog i privlačnog izgleda ako jedan proizvođač (npr. G-Star) stekne isključivo pravo žiga nad specifičnim izgledom traperica koji je kreirao, brandirao i prema kojem je postao prepoznatljiv? Odgovor je - mogu. U konačnici, postavimo si pitanje: mogu li konkurenti na tržištu nuditi zamjenske automobilske dijelove (i pritom pronaći dovoljan broj kupaca koji će im osigurati financijska sredstva za daljnje poslovanje) ako nad vanjskim izgledom originalnog dijela proizvođač ima monopol? Odgovor je - vrlo vjerojatno ne mogu - budući da postoji iznimno mala vjerojatnost da bi na tržištu mogli pronaći dostatan broj kupaca koji bi bili spremni kupiti zamjenski dio koji se prema vanjskim obilježjima ne podudara s vanjskim obilježjima originalnog dijela.

\section{ZAKLJUČAK}

Apsolutna prepreka za registraciju žiga, prema kojoj se kao žig ne može registrirati oblik ili druga karakteristika proizvoda koja značajno determinira vrijednost proizvoda, izaziva niz problema kada ju treba primijeniti u praksi. Njezina primjena podložna je nizu subjektivnih procjena te je gotovo nemoguće predvidjeti odluku nadležnog tijela koja ovisi o njezinoj primjeni. Ovakva situacija negativna je za sve tržišne konkurente koji žele ulagati u dizajn svojih proizvoda i koji svoj brand žele "izgraditi” na dizajnu - budući da ne mogu predvidjeti hoće li takav dizajn moći štititi u permanentnom trajanju (primjenom oblikovnih žigova) ili će se morati ograničiti na vremenski ograničena prava, po čijem će se isteku njihovim dizajnom moći koristiti konkurenti te im (vrlo vjerojatno) i preuzeti dio klijenata. Iako se u literaturi mogu pronaći ekstremni prijedlozi kojima bi se mogla ukloniti pravna nesigurnost koju ova odredba izaziva, takve prijedloge smatramo neprimjerenima.

Prema prvom ekstremnom prijedlogu, trebalo bi de lege ferenda predvidjeti da se kao žig ne mogu registrirati oblici niti druga vanjska obilježja proizvoda. Ovakva odredba de facto bi onemogućila zaštitu većine nekonvencionalnih žigova - što u današnjem poslovnom okruženju, u kojem tržišni takmaci nastoje djelovati na sva osjetila potrošača i u situaciji gdje su potrošači naučili različite vrste marketinških oznaka doživljavati kao razlikovne znakove - ne bi bilo primjereno. Naprotiv, smatramo da bi ovakvo rješenje samo potaknulo nelojalnu konkurenciju. Ako uzmemo u obzir međunarodne izvore žigovnog prava (npr. Sporazum o trgovinskim aspektima prava intelektualnog vlasništva - TRIPS ${ }^{169}$ ) kojima je predviđeno da se kao žig može registrirati bilo koji znak koji potrošači dovode u vezu s podrijetlom proizvoda, ${ }^{170}$ ovakvi prijedlozi (prema kojima bi određene vrste znakova per se bile isključene iz mogućnosti registracije, unatoč činjenici što mogu obavljati funkciju žigova) čine se i protupravnima.

Prema drugom ekstremnom prijedlogu dodatnu prepreku za registraciju žigova, koja je predmet analize u ovom radu, trebalo bi ukinuti jer se njezina svrha može ostvariti pravilom prema kojem se kao žig ne mogu registrirati nerazlikovni znakovi kao što su (u praksi veoma često) oblici ili druge karakteristike proizvoda. U radu smo istaknuli kako je svrha odredbe

169 Sporazum o trgovinskim aspektima prava intelektualnog vlasništva (poznatiji kao Sporazum TRIPS) usvojen je pod okriljem WTO-a, 1994. godine. Objavljen je u Službenom listu EU-a, L 336/214, 23. prosinca 1994. godine.

170 Vidjeti: Sporazum TRIPS, članak 15. 
prema kojoj se kao žig ne mogu registrirati nerazlikovni znakovi, spriječiti mogućnost da se zaštita (u okviru žigovnog prava) osigura i znakovima koji ne obavljaju funkciju žigova, budući da ne ukazuju na porijeklo proizvoda. Za razliku od toga, svrha odredbe prema kojoj se kao žig ne mogu registrirati oblici ili druge karakteristike proizvoda koje značajno determiniraju vrijednost proizvoda, očituje se u zaštiti javnog interesa. Cilj je, dakle, spriječiti neopravdana zadiranja u javnu domenu - neovisno o tome je li znak kojim se neopravdano zadire u javnu domenu razlikovan ili ne. Polazni rationale odredbe o značajnoj vrijednosti oblika (ili druge karakteristike) proizvoda kao apsolutnoj prepreci za registraciju žiga glasi: ne smije postojati monopol nad segmentima, tj. obilježjima proizvoda (uključujući oblik proizvoda) koji su potrošačima privlačni per se (dakle, mimo promidžbenih aktivnosti poduzetnika koji ih je odlučio primijeniti na svojim proizvodima) i to zbog bilo kojeg razloga - npr. jer su estetski lijepi, udobni, zanimljivi, uklapaju se u cjelinu - iako nisu u tehničkom smislu uvjetovani cjelinom i sl. Kada bi nad takvim segmentom (koji potrošači žele - zbog bilo kojeg razloga) postojao monopol, tržišne konkurencije ne bi bilo (ili bi bila značajno ograničena) - što znači da potrošači ne bi imali mogućnost izbora između više proizvoda iste vrste, zbog čega bi interes javnosti bio narušen. Da nema odredbe koja je predmet analize ovog rada, ova se svrha ne bi mogla ostvariti. Stoga, smatramo da je riječ o odredbi koja zaslužuje svoje mjesto u sustavu žigovnog prava, ali koja neminovno vapi za doradom ili barem pojašnjenjem.

Budući da su i "privlačnost” i “značajna vrijednost” promjenjive kategorije koje u velikoj mjeri ovise o subjektivnim procjenama, smatramo kako pri odgovoru na pitanje daju li oblik (ili druga karakteristika) proizvodu značajnu vrijednost, nadležna tijela ne bi trebala naglasak stavljati na ocjenu je li riječ o proizvodu koji je privlačan, već na činjenicu postoji li stvarna i opravdana potreba konkurenata da svoje proizvode nude $\mathrm{u}$ istovjetnom obliku. Trebalo bi se, dakle, usredotočiti na ratio odredbe i postaviti pitanje: mogu li konkurenti (realno) nuditi istu vrstu proizvoda, drugačijeg izgleda, ako bi se nekome dodijelilo žigovno pravo nad oblikom proizvoda? Ako je odgovor pozitivan - žigovnu zaštitu ne bi trebalo uskratiti jer bi takvo postupanje samo potaknulo tzv. free riding koji narušava zdravu tržišnu utakmicu te u konačnici šteti potrošačima. Ako je odgovor negativan - tada bi žigovnu zaštitu trebalo uskratiti jer bi u suprotnom nositelj žiga stekao neopravdanu prednost na tržištu pred ostalim konkurentima, što bi mu (u konačnici) moglo omogućiti da na tržištu stekne vremenski neograničen monopolski položaj, što je protivno interesima javnosti.

Da bi ovo pravilo moglo ostvariti svoj ratio bez negativnih popratnih posljedica, smatramo da ga je potrebno primijeniti prema sljedećim uputama koje smo pripremili imajući u vidu njegovu svrhu (s jedne strane) te probleme do kojih dolazi njegovom primjenom u praksi (s druge strane):

- odredbu prema kojoj kao žig nije moguće registrirati oblik proizvoda koji značajno utječe na vrijednost proizvoda, treba ciljano tumačiti tako da se primjenjuje na sve vanjske karakteristike proizvoda (ne samo na oblike u užem smislu riječi) i kada je riječ o žigovima koji su registrirani prije nego što su na snagu stupile izmjene žigovnog prava iz 2015. godine - dakle, i takve je žigove moguće utvrditi ništetnima (iako se na njih ne primjenjuju legislativna rješenja iz 2015. godine, u kojima izričito stoji kako se ova prepreka za registraciju žigova odnosi na bilo koju karakteristiku proizvoda koja značajno determinira njegovu vrijednost) 
- $\quad$ primjenjuje se uvijek kada bi monopoliziranje takve vanjske karakteristike proizvoda moglo isključiti ili značajno ograničiti tržišnu konkurenciju (neovisno o tome očekuju li kupci takvu karakteristiku kod drugih proizvoda iste vrste zato što je estetski privlačna ili zbog nekog drugog razloga)

- ocjenjuje se je li ta karakteristika bila nužna konkurentima i prije nego što ju je jedan od tržišnih konkurenata počeo koristiti na tržištu - ako im nije bila potrebna, pretpostavlja se da njezina vrijednost proizlazi iz ugleda proizvođača ili je posljedica njegovih promidžbenih aktivnosti - iz toga proizlazi da mu pripada pravo na zaštitu u okviru žigovnog prava (ako su zadovoljeni ostali uvjeti za registraciju žiga).

\section{LITERATURA}

1. Brancusi, L., Trade Marks' Functionality in EU Law : Expected new Trends after the Louboutin case, European Intellectual Prooperty Review, god. 41, br. 2, 2019., str. 98.-106.

2. Cornish, W. R.; Llewelyn, D.; Aplin, T., Intellectual Property: Patents, Copyright, Trade Marks and Allied Rights - eight edition, Sweet and Maxwell, London, UK, 2013.

3. Gangjee, D. S., Paying the Price for Admission: Non-Traditional Marks across Registration and Enforcement, objavljeno u: Calboli, I.; Senftleben, M. (ur.), The Protection of non-trdaitional marks: critical perspectives, Oxford University Press, Oxford, UK, 2018., str. 1.-28.

4. Gielen, C., Substantial Value Rule: How it Came into Being and Why it Should be Abolished, European Intellectual Property Review, br. 3, 2014., str. 164.-169.

5. Hughes, J., Cognitive and aesthetic functionality in trademark law, Loyola - LA Legal studies paper, br. 2015-07, 2015., str. 100.-156.

6. Karjala, D., Sustainability and Intellectual Property Rights in Traditional Knowledge, Jurimetrics, god. 53, 2012., str. 57.-70.

7. Krpan, P., Nekonvencionalni žigovi, Pravnik, god. 48, br. 1 (96), 2014., str. 63.-74.

8. Kur, A.; Senftleben, M., European Trademark Law - A Commentary, Oxford University Press, Oxford, UK, 2017.

9. Kur, A., Too common, too splendid or just right? Trademark protection for product shapes in light of CJEU case law, Max Planck Institute for Innovation and Competition Research Paper Series, Research Paper, br. 14-17, 2014., str. 1.-30.

10. Kur, A., Too Pretty to Protect? Trade Mark Law and Enigma of Aesthetic Funcionality, Max Planck Institute for Intellectual Property and Competition Law Research Paper, Research Paper br. 11-16, 2011., str. 1.-22.

11. Maniatis, S., Whither European trademark law? Arsenal and Davidoff: the creative disorder stage, Marquette Intellectual Property Law Review, god. 7, br. 1, 2003., str. 99.-147.

12. Rački Marinković, A., Apsolutni i relativni razlozi za odbijanje registracije žiga: usporedba nekih aspekata europskog i hrvatskog prava te prakse OHIM-a i DZIV-a, objavljeno u: Matanovac Vučković, R. (ur.), Hrvatsko pravo intelektualnog vlasništva u svjetlu pristupanja Europskoj uniji, Narodne novine i Državni zavod za intelektualno vlasništvo, Zagreb, 2006., str. 1.-52.

13. Rosati, E., The absolute ground for refusal or invalidity in Article 7 (1) (e) (iii) EUTMR / 4 (1) (e) (iii) EUTMD: in search of the exclusion's own substantial value, Journal of Intellectual Property Law \& Practice, god. 15, br. 2, 2020., str. 103.-122. 


\section{POPIS PROPISA, AKATA I SUDSKIH ODLUKA}

1. August Storck KG v OHIM, C-25/05, od 22. lipnja 2006.

2. Bang \& Olufsen A/S v OHIM (Shape of a loudspeaker II), T-508/08, od 6. listopada 2011.

3. Bang \& Olufsen A/S v OHIM, T-460/05, od 10. listopada 2007.

4. Benetton Group SpA v G-Star International BV, C-371/06, od 20. rujna 2007.

5. Chocoladefabriken Lindt \& Sprüngli AG v OHIM, C-98/11, od 24. svibnja 2012.

6. Christian Louboutin, Christian Louboutin SAS v Van Haren Schoenen BV, C-163/16, od 12. lipnja 2017.

7. Deutsche SiSi-Werke GmbH \& Co. Betriebs KG v OHIM, C-173/04 P, od 12. siječnja 2006.

8. Direktiva 89/104 EEZ od 21. prosinca 1988. godine o usklađivanju zakonodavstava država članica o žigovima, Službeni list EU-a, L 40 (11. veljače 1989.), str. 1.-7.

9. Direktiva 2008/95/EZ od 22. listopada 2008. godine o usklađivanju zakonodavstava država članica o žigovima - kodificirana verzija, Službeni list EU-a, L 299/25 (8. studenoga 2008.), str. 149.-157.

10. Direktiva (EU) 2015/2436 Europskog parlamenta i Vijeća od 16. prosinca 2015. godine o usklađivanju zakonodavstava država članica o žigovima, Službeni list EU-a, L 336/1 (23. prosinca 2015.), str. 1.-26.

11. Gömböc Kutató, Szolgáltató és Kereskedelmi Kft. v Szellemi Tulajdon Nemzeti Hivatala, C-237/19, od 23. travnja 2020.

12. Hauck GmbH \& Co. KG v Stokke A/S and Others, C-205/13, od 18. rujna 2014.

13. Henkel v. OHIM, C-456/01 P i 457/01 P, od 29. travnja 2004.

14. Koninklijke Philips Electronics NV v Remington Consumer Products Ltd., C-299/99, od 18. lipnja 2020.

15. Lego Juris A/S v. OHIM, C-48/09, od 14. rujna 2009.

16. Libertel Groep BV protiv Benelux-Merkenbureau, C-104/01, od 6. svibnja 2003.

17. Linde AG, Winward Industries Inc. i Rado Uhren AG, C-53/01 - C-55/01, od 8. travnja 2003.

18. Louis Vuitton Malletier v OHIM, C - 97/12, od 15. svibnja 2014.

19. Mag Instrument Inc. v OHIM, C-136/02 P, od 7. listopada 2004.

20. Matratzen Concord AG v Hukla Germany SA, C-421/04, od 9. ožujka 2006.

21. OHIM, Fifth Board of Appeal, Case R 942/2012-5, od 16. siječnja 2013.

22. OHIM, First Board of Appeal, Case R 497/2005-1, od 22. rujna 2005.

23. OHIM, Third Board of Appeal, Case R 395/1999-3, od 3. svibnja 2000.

24. OHIM v Erpo Möbelwerk, C-64/02 P, od 21. listopada 2004.

25. Procter \& Gamble Company v OHIM, C-468/01 P - C-472/01 P, od 29. travnja 2004.

26. Ralf Sieckmann v Deutsches Patent- und Markenamt, C-273/00, od 12. prosinca 2002.

27. Savezna Republika Njemačka, Savezni patentni sud (BPatG), predmet Kraftfahrzeugteile, iz 2005. godine.

28. Savezna Republika Njemačka, Savezni patentni sud (BPatG), predmet Schmuckring, iz 2001. godine.

29. Savezna Republika Njemačka, Vrhovni sud Savezne Republike Njemačke (BGH), predmet Fronthaube, iz 2008. godine.

30. Sporazum o trgovinskom aspektima prava intelektualnog vlasništva, objavljen u Službenom listu EU-a, L 336/214 (23. prosinca 1994.), str. 228.-247. 
31. Textilis Ltd, Ozgur Keskin v Svenskt Tenn AB, C-21/18, od 14. ožujka 2019.

32. Yoshida Metal Industry Co. Ltd. v OHIM, T - 331/10, od 8. svibnja 2012.

33. UK, Žalbeni sud Engleske i Walesa (civilni odjel), The London Taxi Corporation Ltd ( $\mathrm{t} / \mathrm{a}$ the London Taxy Company) v Frazer-Nash Research Ltd \& Anor, od 1. studenoga 2017.

34. Uniform Trade Mark Act of the Benelux contries (Benelux Merkenwet, BMW), 1975.

35. Uredba (EU) 2015/2424 Europskog parlamenta i Vijeća od 16. prosinca 2015. godine o izmjeni Uredbe Vijeća (EZ) br. 207/2009 o žigu Zajednice i Uredbe Komisije (EZ) br. 2868/95 o provedbi Uredbe Vijeća (EZ) br. 40/94 o žigu Zajednice te o stavljanju izvan snage Uredbe Komisije (EZ) br. 2869/95 o pristojbama koje se plaćaju Uredu za usklađivanje na unutarnjem tržištu (žigovi i dizajni), Službeni list EU-a, L 341/21 (24. prosinca 2015.), str. 21.-94.

36. Uredba (EU) 2017/1001 Europskog parlamenta i Vijeća od 14. lipnja 2017. godine o žigu Europske unije, Službeni list EU-a, L 154/1 (16. lipnja 2017.), str. 1.-99.

37. Zakon o žigu, Narodne novine, broj 14/2019.

\section{MREŽNI IZVORI}

1. Biberović, M., Slučaj Borboleta: Zaštitila dizajn, narušila si ugled, 19. srpnja 2019. https://www.netokracija.com/borboleta-zastita-dizajna-tuzbe-159106. Pristupljeno 15. travnja 2020.

2. Državni zavod za intelektualno vlasništvo. https://www.dziv.hr/hr/intelektualno-vlasnistvo/o-intelektualnom-vlasnistvu/. Pristupljeno 1. veljače 2020.

3. Državni zavod za intelektualno vlasništvo. https://www.dziv.hr/hr/intelektualno-vlasnistvo/zigovi/. Pristupljeno 1. veljače 2020.

4. European Union Intellectual Property Office, EUIPO Examination Guidelines. https://guidelines.euipo.europa.eu/1803468/1786987/trade-mark-guidelines/2-shape-or-other-characteristics-resulting-from-the-nature-of-the-goods. Pristupljeno 2. svibnja 2020.

5. Max Planck Institute for Intellectual Property and Competition Law, Study on the Overall Functioning of the European Trade Mark System, Munich, 2011. https://www.ip.mpg.de/fileadmin/IP/pdf2/ mpi-final-report-with-synopsis.pdf. Pristupljeno 28. travnja 2020.

6. Szpunar, M., Opinion of Advocate General Szpunar in Christian Louboutain and Christian Louboutain Sas v van Haren Schoenen BV, od 22. lipnja 2017. http://curia.europa.eu/juris/document/document. jsf?text $=\&$ docid $=192069 \&$ pageIndex $=0 \&$ doclang $=E N \&$ mode $=$ req $\&$ dir $=\& o c c=$ first $\&$ part $=1 \&$ cid=1682285. Pristupljeno 7. travnja 2020.

7. Tekst Ustava SAD-a. http://constitutionus.com/. Pristupljeno 1. veljače 2020. 


\section{SUBSTANTIAL VALUE OF A PRODUCT SHAPE AS AN ABSOLUTE GROUND FOR TRADEMARK REFUSAL}

\section{Summary}

The paper provides a comprehensive analysis of "substantial value rule" as an absolute ground for trademark refusal. Originating from the US "aesthetic functionality doctrine", the rule took a specific form in the EU. There it was incorporated in Directive (EU) 2015/2436 to approximate the laws of the Member States relating to trade marks - Article 4 (1) (e) (iii), as well as in Regulation (EU) 2017/1001 on the European Union trade mark - Article 7 (1) (e) (iii). Pursuant to "substantial value rule", signs consisting exclusively of the shape that gives substantial value to the goods are not to be registered as trademarks or, if registered, are liable to be declared invalid.

The objective of the paper is therefore threefold: a) to define the rationale of "substantial value rule"; b) to analyze relevant case law; c) to conclude whether a respective rule shall be abolished (providing its purpose may be achieved by other legal instruments without negative side-effects) or kept in the EU trademark law system.

Bearing in mind the rationale of "substantial value rule" (on the one hand) and numerous problems that arise whenever "substantial value rule" is applied in practice (on the other hand) the paper provides guidelines for its appropriate interpretation.

Keywords: $\quad$ substantial value rule, aesthetic functionality doctrine, absolute grounds for trademark refusal, shape marks, 3D trademarks

\section{(c) (i) $\$$}

This work is licensed under a Creative Commons

Attribution-NonCommercial 4.0 International License.

Tea Hasić, Lecturer, Faculty of Economics and Tourism “Dr. Mijo Mirković”, Juraj Dobrila University of Pula, Preradovićeva 1/1, 52100 Pula. E-mail address: thasic@unipu.hr. ORCID: https://orcid.org/0000-0001-6079-1156. 